تأثير بقاياى گياه فسكيوى بلند در حضور قارج اندوفيت Epichloë coenophaila بر آبگريزى و پايدارى ساختمان خاكهاى با بافت متفاوت

\author{
فاطمه حسينى "، محمد رضا مصدقى '، محمد على حاجعباسى'، محمد رضا سبزعليان'؛

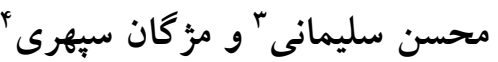

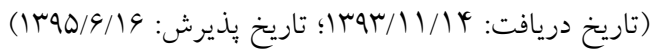

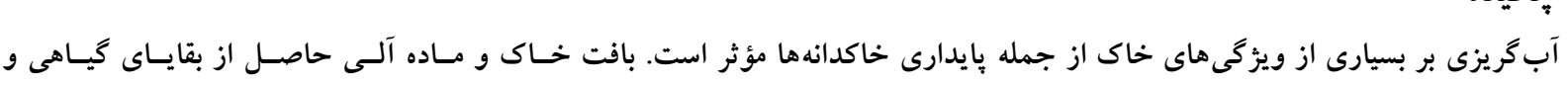

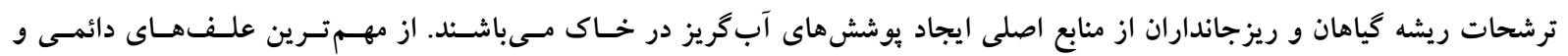

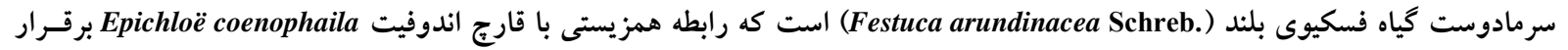

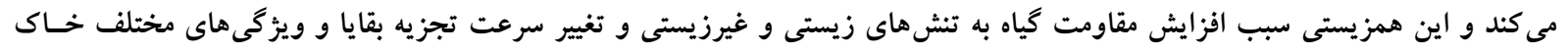

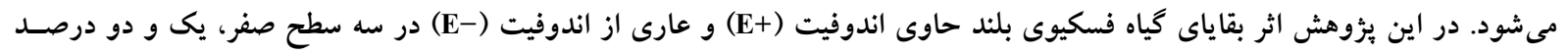

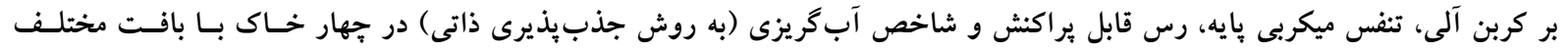

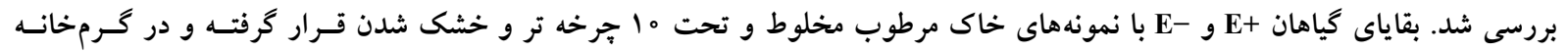

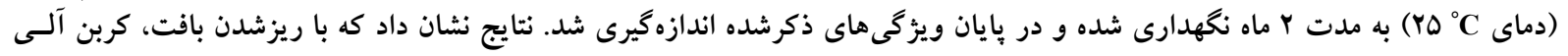

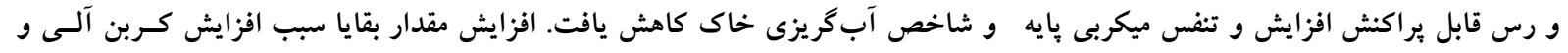

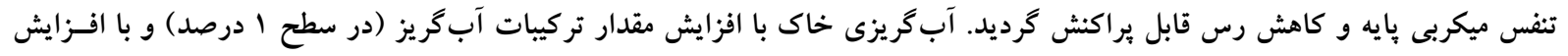

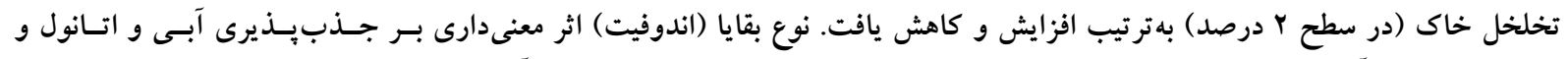

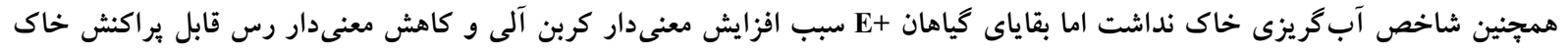

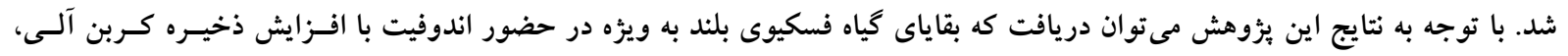

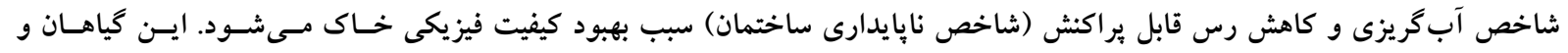

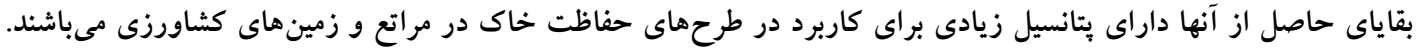

وازههاى كليدى: شاخص آبكريزى، اندوفيت، رس قابل براكنش، فسكيوى بلند، جذبذيرى آب، جذبذيرى اتانول

ا. كُوه علوم خاك، دانشكده كشاورزى، دانشگاه صنعتى اصفهان

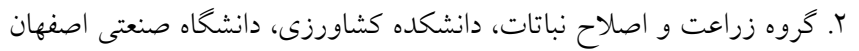

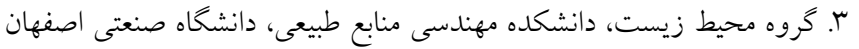

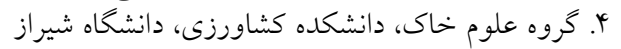

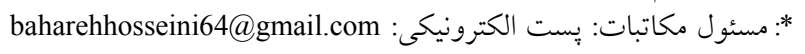


آب گريزى خاك و در نتيجه كاهش بيامدهاى مخـرب ناشسى از

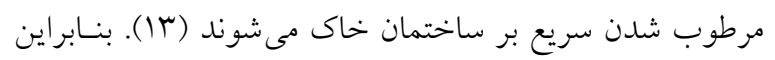

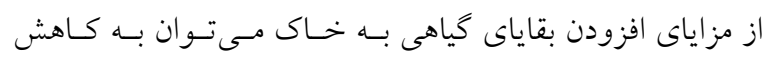

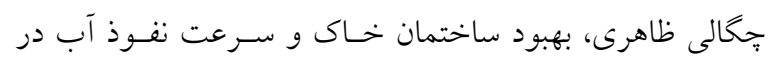

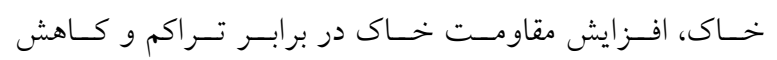
فرسايش يذيرى خاك اشاره كرد (9).

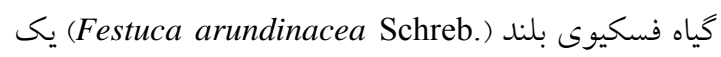

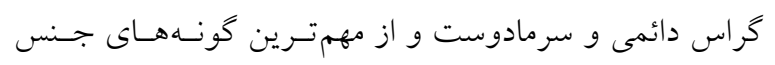

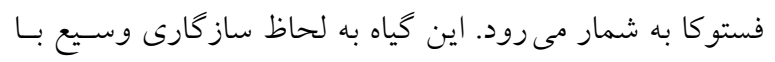
شرايط محيطى از نظر توليد علوفـه، احيـاى مراتـع و احسـاث

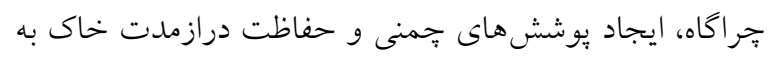

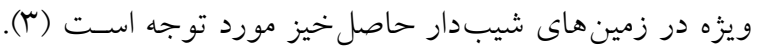

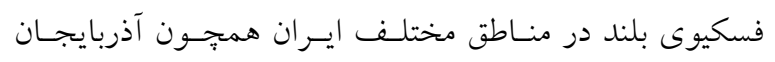

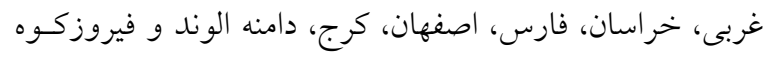

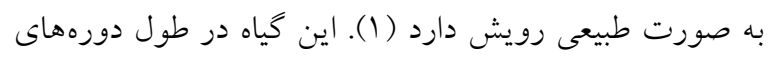

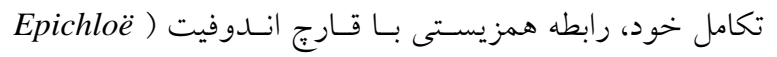
coenophaila طريق ترشح آلكالوئيدها و تركيبات فنلى سبب ايجاد تغييـرات

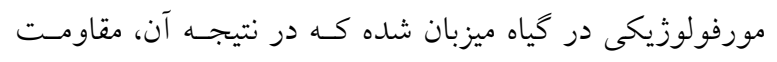

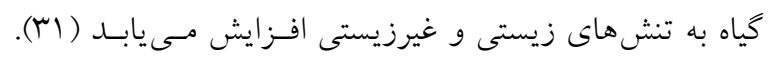

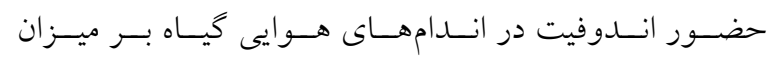

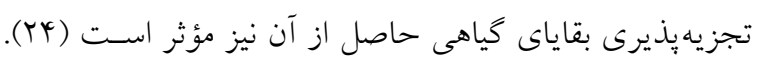

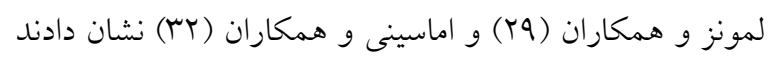

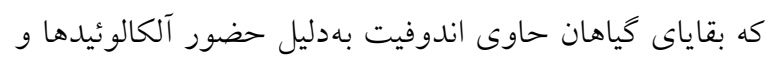

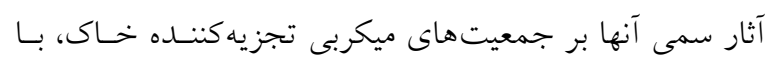

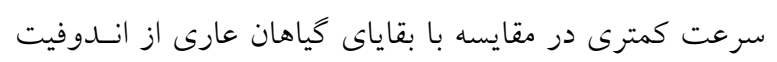

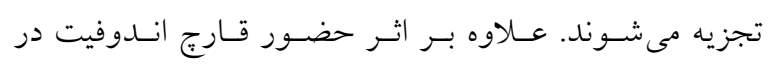

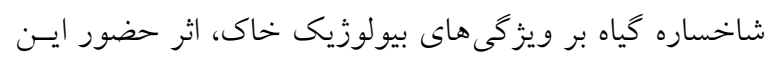

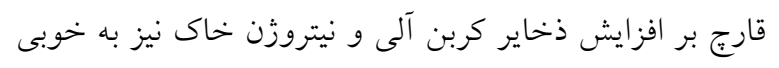

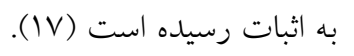

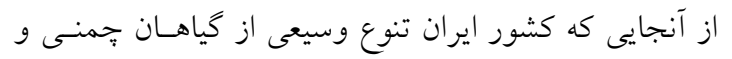

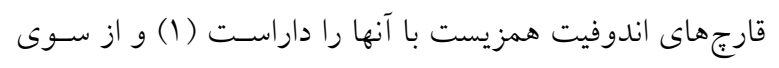

\section{مقدمه}

حضور يوشش هاى آبكريز روى سطوح ذرات و خاكدانههـا و

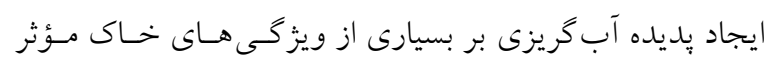

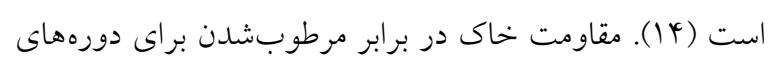

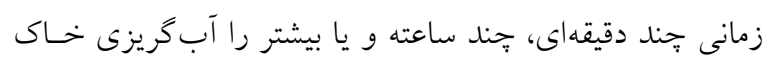

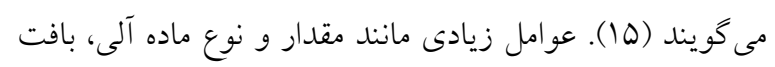

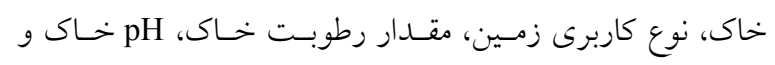

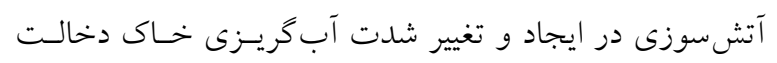

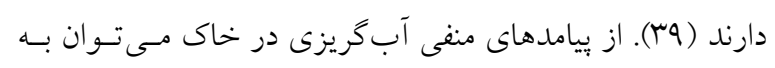

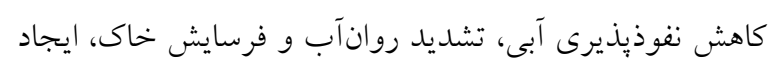

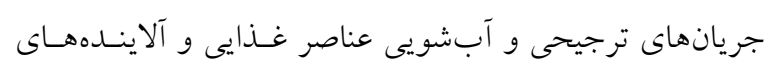

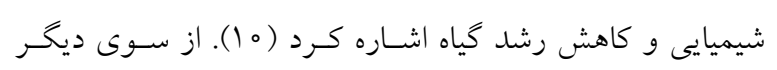
يديده آب گريزى (خفيف تا متوسط) داراى بيامدهاى مثبت نيـز

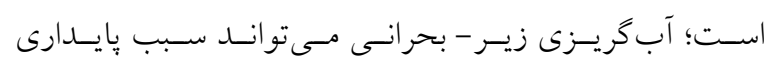

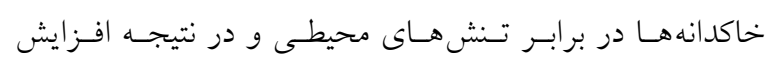

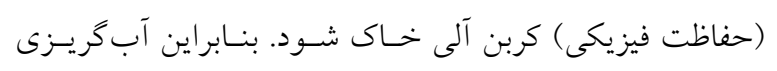

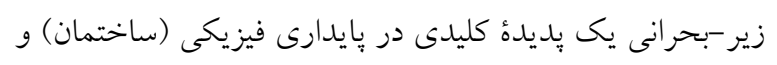

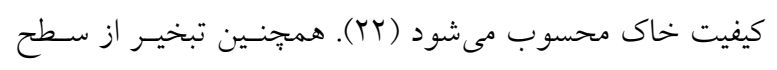

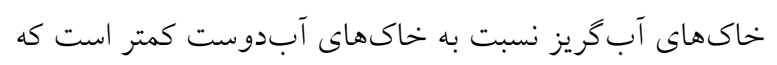

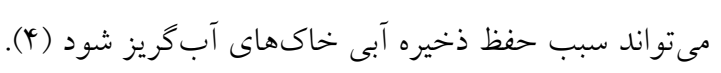

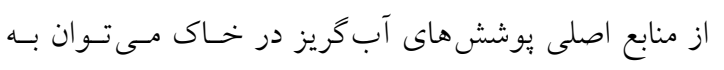

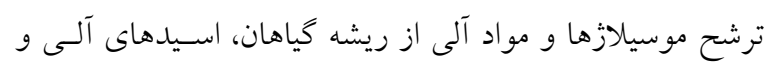

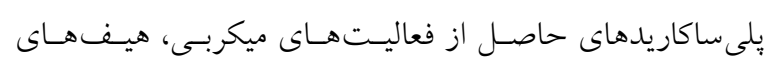

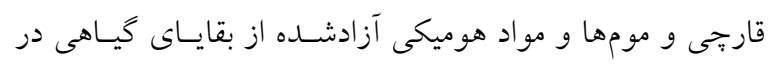

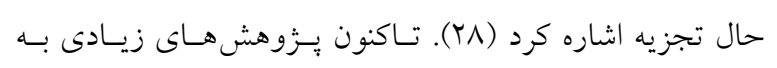

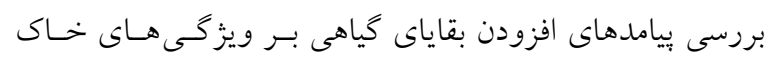

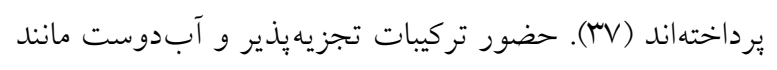

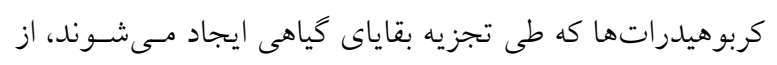

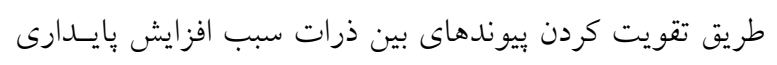

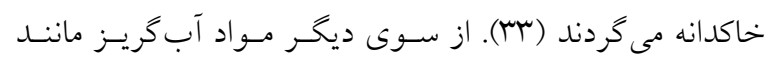

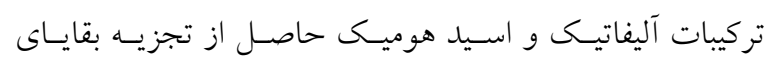

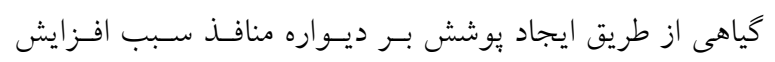


تأثير بقاياى كياه فسكيوى بلند در حضور و عدم حضور قارج اندوفيت ...

\begin{tabular}{|c|c|c|c|c|c|c|c|c|c|}
\hline \multirow{2}{*}{$\mathrm{pH}$} & رسانايى الكتريكى & كربن آلى & كربنات كلسيم & شن & سيلت & رس & \multirow{2}{*}{ بافت } & \multirow{2}{*}{ مكان } & \multirow{2}{*}{ شماك } \\
\hline & (دسىزيمنس بر متر) & \multicolumn{5}{|c|}{ كرم بر كيلوگرم } & & & \\
\hline$\Lambda / 1$ & $T / V$ & $0 / \Delta 1$ & YAT & TUT & $\uparrow \wedge V$ & 191 & لوم & خمينى شهر & 1 \\
\hline $\mathrm{V} / \mathrm{A}$ & $T / T$ & $\Delta / \wedge \varphi$ & yor & req & rлм & TAT & 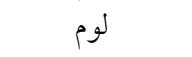 & نجف آباد & r \\
\hline $\mathrm{V} / \mathrm{A}$ & $T / Q$ & $9 / N r$ & $Y \Delta Q$ & 100 & 0.9 & rیs & لوم رسى سيلتى & اصفهان & $r$ \\
\hline $\mathrm{V} / \mathrm{\Lambda}$ & $T / \mathcal{C}$ & $4 / 10$ & pll & 111 & YOS & Frs & رس سيلتى & اصفهان & $r$ \\
\hline $1 / 9$ & $\Lambda / \Delta$ & N/DT & V & 90 & 11 & rq & - & - & $\mathrm{CV}$ \\
\hline
\end{tabular}

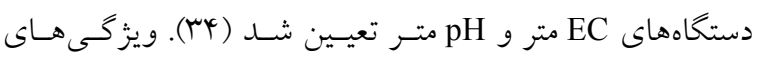
فيزيكى و شيميايى خاى هاى مورد بررسى در جدول (1) ارائسه شده است. كياه مورد آزمايش، فسكيوى بلند بود كه يس از جمـعَآورى

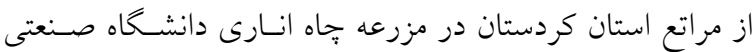
اصفهان كشت شده و ينجههاى آن بهطـور طبيعى داراى قـارج اندوفيت بودند. آلوده بودن كامل كياه به قارج انسدوفيت توسط روش رنخآميزى غلاف برى با استفاده از رنخ رز بنخال تعيين

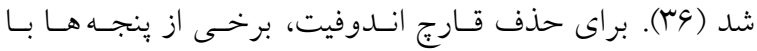
مخلوط دو قارج كش به نـامهـاى بروييكونـازول و تبوكونـازول بهترتيب با مقادير ا ميلىليتـر در ليتـر و ب گــرم در ليتـر تيمـار شدند (ها). بقاياى گياهى از شاخسـاره فسـكيوى بلنـد حــاوى

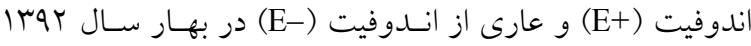
برداشت شد. بقايا به آزمايشـاه منتقـل و در دمــاى ه4 درجــه سلسيوس خشك شد. بقاياى گياهى آسياب گرديـده و از الـى يك ميلى مترى عبور داده شدند. برخى از ويز كى هاى بقايا شامل

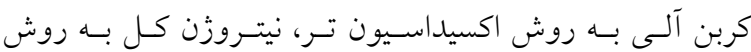
كجلدال، نسبت كـربن بــهـ نيتـروزن، و غلظــت تركيبـات فنلـى محلول در آب به روش كونـع و همكــاران انــازه خيـرى شـــ (جدول (TV) (TV). براى اندازهگيرى غلظت تر كيبات فنلى محلول در آب، يك ميلى گرم از بقاياى گياه فسكيوى بلند در ^ ميلى ليتر آب مقطر به مدت ع T ساعت با سرعت ه ما دور در دقيقه تكان داده و با كاغذ صافى واتمن ب ب صاف شد. در عصـاره حاصـل، مقدار تركيبات فنلى با معرف فولين - سيو كالتيو اندازه كيرى شــ

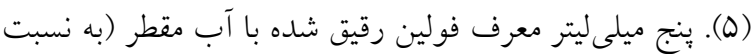

ديخر در شرايط كنونى، مراتع كشور قادر به تأمين علوفـه مـورد نياز دامها و حفاظت خاك نيستند، بنابراين زمينه مناسـبى بـراى استفاده از اين كياهان و قارجهاى همزيست با آنها و همجٍنـين بقاياى آنها در طرحهاى احيا مراتع و حفاظت خاى وجود دارد. بـا ايسن حسال ايسن گياهـان كمتـر مــورد توجـهـ قـرار گرفتـه و

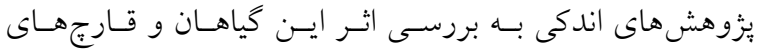

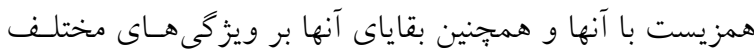
خاك يرداختهاند. اين يزوهش با هدف بررسى اثـر نـوع خـاك،

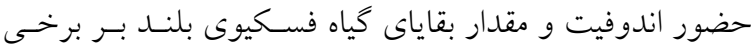
ويزخى هــاى شـيميايى، بيولوزيـــ و هيـدروليكى، و بايــارى

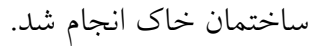

\section{مواد و روش ها} نمونهبردارى خاك و تهيه بقاياى گياهى براى انجام اين يزوهش، جهار نوع خاك از مزارع اطـراف شـهر اصفهان انتخاب شد كه از نوع خاكهاى آهكى با كربن آلى كـم تهم بودند (جدول (). ويز كىهاى اوليه خاكها بـهـ جـز بافـت آنهـا شباهت زيادى به يكديخر داشت؛ بنابراين بررسى اثر بافـت بـر

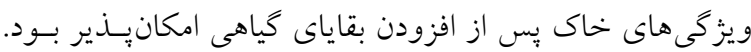
در باييز |وب| نمونههاى خاك از لايه صـفر تـا هب سـانتى متـر برداشت شده و يس از هوا-خشك شدن بـه آزمايشـعاه منتقـل كرديد. نمونهها از الك r ميلى مترى عبور داده شد و ويز گیى هاى خــاك شـامل بافـت بــه روش بييــت، كـربن آلـى بــه روش اكسيداسيون تـر، كربنـات كلسـيم معـادل بـه روش تيتراسـيون بركشتى و رسانايى الكتريكسى و pH كـل اشـبـاع بــترتيـب بـا 
نشر يه علوم آب و خاك (علوم و فنون كشاورزى و منابع طبيعى) / سال بيست و يك / شماره دو / تابستان وهـ1

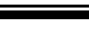

جدول r. برخى از ويزگگىهاى شيميايى بقاياى گياهى حاوى اندوفيت (E+) و عارى از اندوفيت (E)

\begin{tabular}{|c|c|c|c|}
\hline 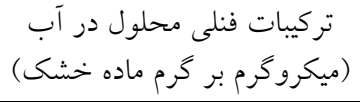 & نسبت كربن به نيتروزن (C/N) & 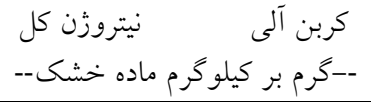 & وع بقايا \\
\hline$r \wedge \vee \circ / 9$ & $1 \wedge 9 / 19$ & $r / \Delta \wedge \quad Y \wedge Y / r$ & $\mathrm{E}+$ \\
\hline$Y Y Q \circ / D$ & $10 Y / O Y$ & $49 \pi / 9$ & $\mathrm{E}-$ \\
\hline
\end{tabular}

اعمال شد. در فاصله زمانى ميان جرخههاى تـر-خشـك شــن،

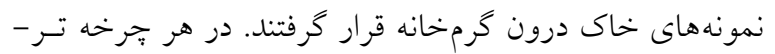
خشك شدن، رطوبت خاك توسط يل آبى به گنجـايش زراعسى رسانده شد و به مدت ع (FC)

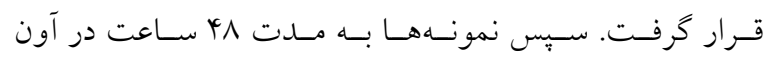
هو اكشدار با دماى ها درجه سلسيوس قـرار گرفتـه و خشـى

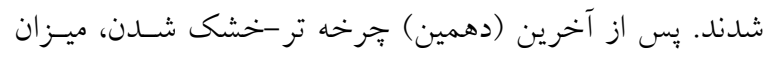

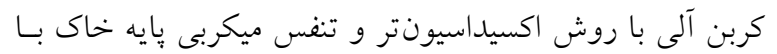

روش جن و همكاران اندازهيرى شد (11).

\section{اندازهيرى آبكريزى خاك}

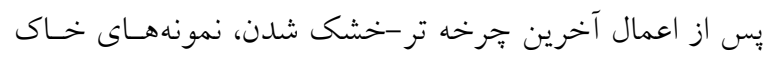

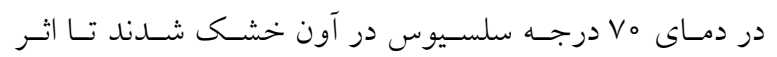
رطوبت اوليه خاى بر آب گريزى در تيمارهاى مختلـف حسذف لـ

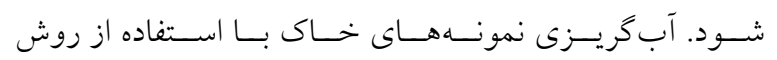
جذبـيذيرى ذاتى اندازه كيرى شد. در ايسن روش بـا اسـتفاده از

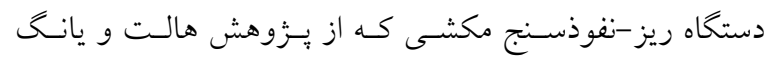
الكوبردارى شد، ميزان جذب آب مقطر و اتـانول (هو درصـد) توسط خاك، تحت شرايط نزديك اشباع (يتانسيل ماتريك يـا

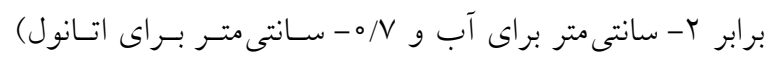
اندازه گيرى شد (ب0). شـكل (1) شـماى كلى ريـز -نفوذسـنج مكشى استفاده شده در اين ئزوهش را نشان مى مهد. اساس اندازه گيرى آبكريزى خـاى در ايسن روش تفـاوت جذب يذيرى خاى براى آب و اتانول اسـت. آرايسش (هندسـه)

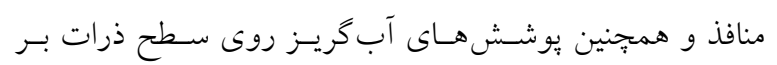
جذبِيذيرى آبى خاى مؤثر است ولى جذب يذيرى اتانول تنهـا

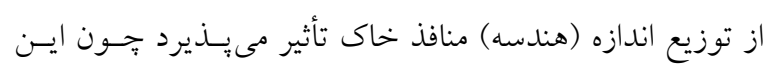
سيال تمامى سطوح و ذرات خاك را مستقل از آبكريزى خيس
ا به ه () به ا ميلى ليتر از عصاره استخراج شده افـزوده شــه و ميزان جذب در طول موج V9 نانومتر با دستخاه اسبكتروفتومتر قرائت شد. اسيد وانيليك بهعنوان استاندارد استفاده شد و مقدار تركيبات فنلى محلول در آب برحسب ميكروگرم بـر گـرم وزن خشك بقايا كزارش شد.

آمادهسازى نمونههاى خاى نمونه هاى خاى مخلوطشده با بقايا در سـيلندرهـاى اسـتيل بــه

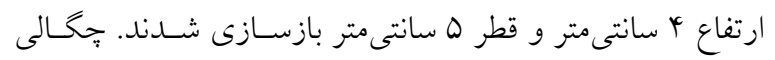
ظاهرى مناسب (بهينه براى رشد گياه) براى بازسازى نمونههاى

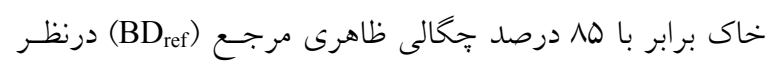
كرفته شد. تعيين BD بر اسـاس روش هكنسـون تحست تـنش

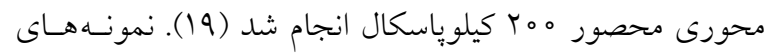
خاك هوا-خشك شده از الك r ميلى مترى عبور داده و بقايـاى كياه فسكيوى بلند حاوى اندوفيت و عارى از انـدوفيت در سـهـ سطح صفر، ا و r درصـد براسـاس وزن خشكى بـه خـاكهـا افزوده شد. رطوبت نمونههاى خاك به حد خميرى رسانده شد. خاك مرطوب درون بِاكت هاى بِلاستيكى قرار گرفته و به مدات ^ץ ساعت در دماى ب درجه سلسيوس نخهدارى شد تا رطوبت با تمام نمونه خاك به تعادل رسيده و توزيع آن در نمونه خـاك لـاك يكنواخت گردد. در نهايت خاك مرطوب در سيلندرهاى استيل

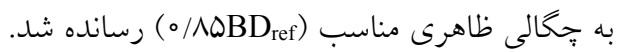
اعمال جرخه هاى تر -خشك شدن يّ از بازسازى نمونههاى خاك، نمونهها بـهـ مـات دو مـاه در كرمخانه با دماى هr درجه سلسيوس نخهدارى شـدند. در ايسن

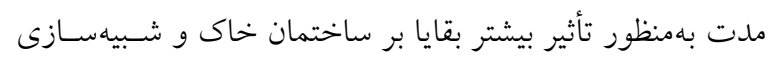
شرايط طبيعى، •ا جرخحه تر -خشك شدن بر نمونه هـاى خـاك 


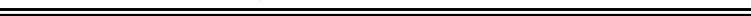

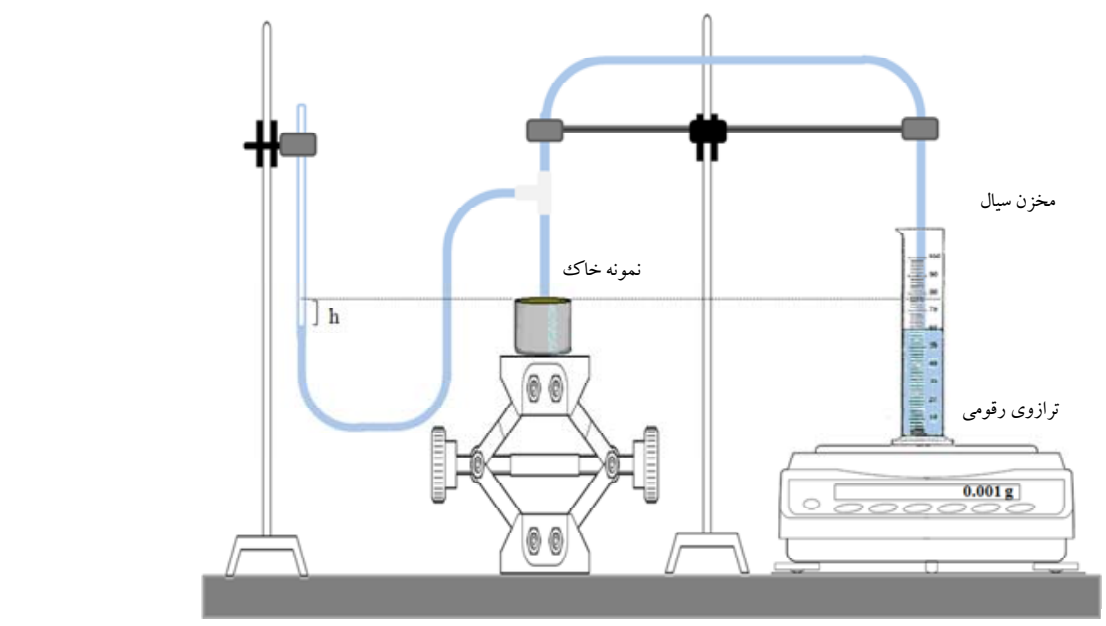

شكل ا. شماى كلى دستخاه ريز-نفوذسنج مكشى براى اندازگيرى جذبيذيرى آبى و اتانول و آبكريزى خاك

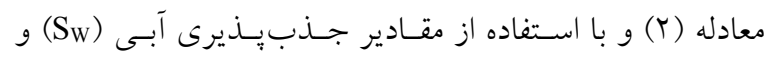

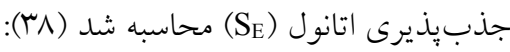
$\mathrm{RI}=1 / 9 \Delta \times \frac{\mathrm{S}_{\mathrm{E}}}{\mathrm{S}_{\mathrm{W}}}$

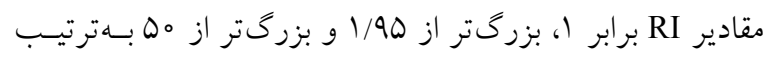

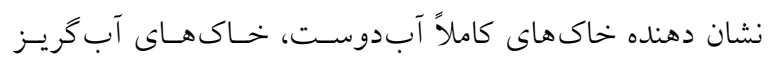

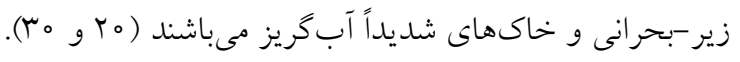

اندازءيرى رس قابل براكنش خاى

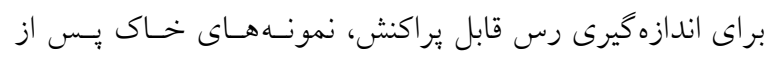

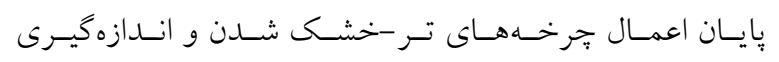

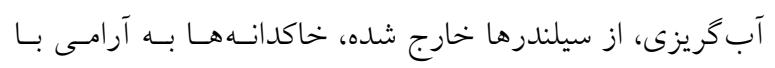

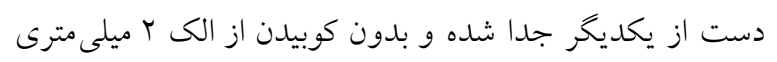

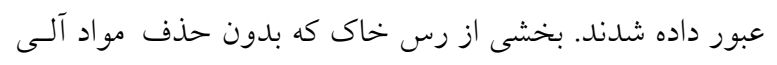

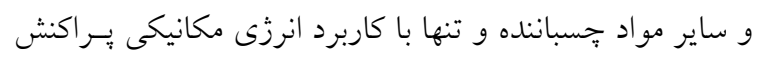

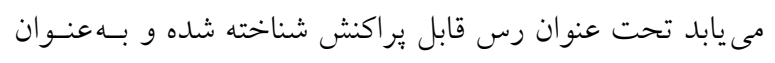

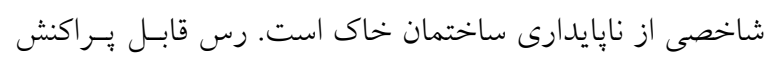

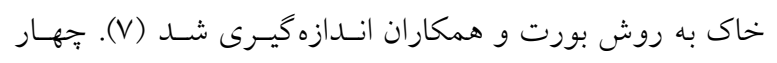

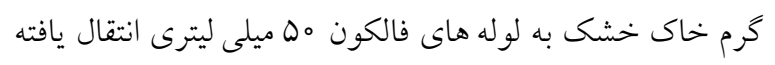

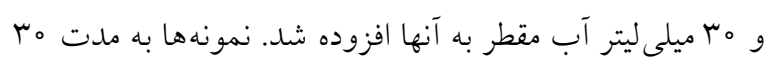

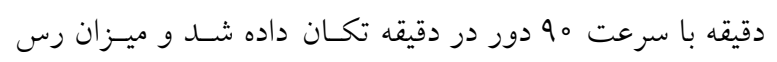

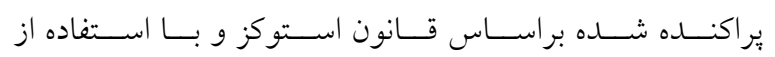

مى كند (YN). در ابتداى فرآيند نقوذ، جريان سـيال تحـت تـأثير

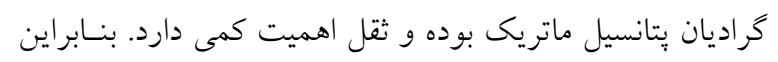

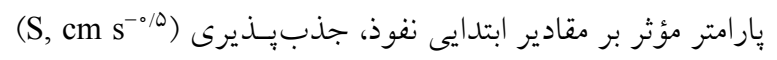

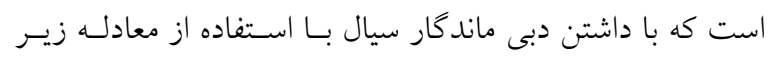
محاسبه شد: $\mathrm{S}=\sqrt{\frac{\mathrm{Qf}}{\mathrm{rbr}}}$

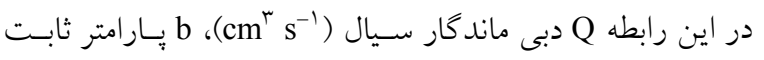

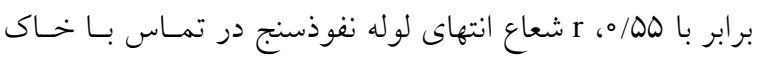

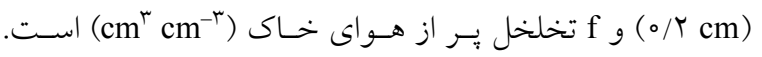

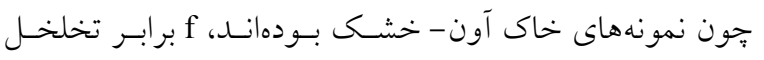

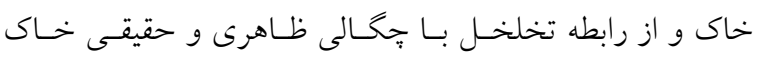

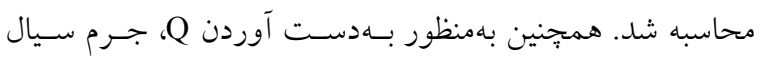

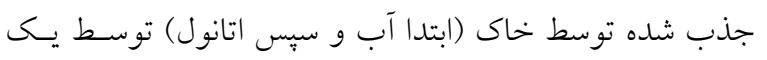

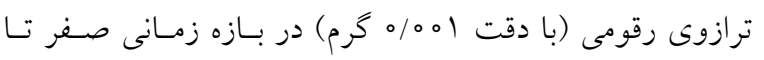

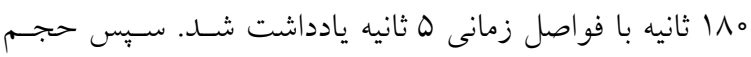

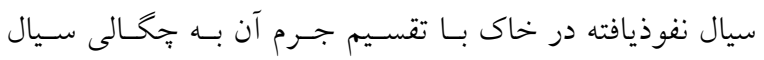

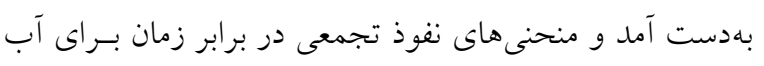

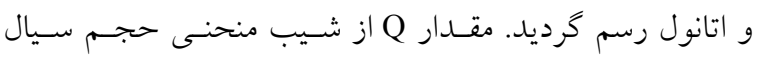

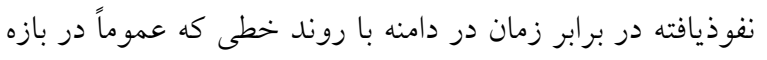

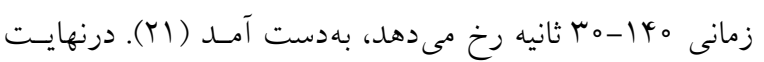

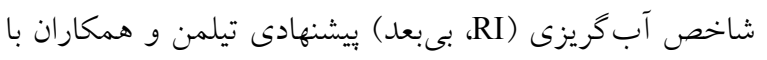




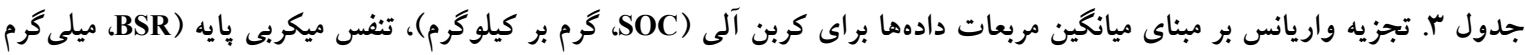

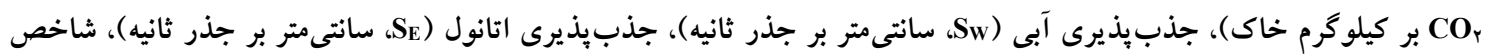

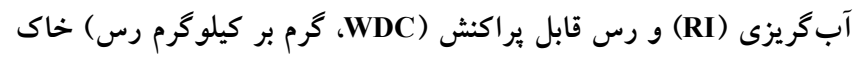

\begin{tabular}{|c|c|c|c|c|c|c|c|}
\hline \multicolumn{6}{|c|}{ MSE } & \multirow{2}{*}{ داز درجه } & \multirow{2}{*}{ منابع تغييرات } \\
\hline WDC & RI & $\mathrm{S}_{\mathrm{E}}$ & $\mathrm{S}_{\mathrm{W}}$ & BSR & SOC & & \\
\hline & & & & & & 19 & تيمار \\
\hline MIOV *** & 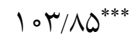 & $0 / 000 / f^{\mathrm{ns}}$ & $\circ / \circ \circ \varphi^{\mathrm{ns}}$ & FATrY*** & KY/Y人 *** & r & بافت خاى \\
\hline ryYa* & $r \mu / D 1^{* * *}$ & $\circ / \circ \circ \circ \circ V^{n s}$ & $\circ / \circ \circ \wedge q^{\mathrm{ns}}$ & $|r \mu \circ| \Lambda^{* * *}$ & $111 / 9 \Lambda^{* * *}$ & 1 & مقدار بقايا \\
\hline rV৭9 ** & $\circ / \circ \Delta^{\mathrm{ns}}$ & $\circ / 0 \circ 0 Y \varphi^{\mathrm{ns}}$ & $0 / 0099$ ns & 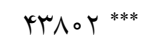 & $4 / 11^{* * *}$ & 1 & نوع بقايا \\
\hline rard *** & $\mid \Gamma / V \varphi^{* * *}$ & $\circ / \circ \circ \circ \mu_{\circ} n s$ & $\circ / \circ \circ \Delta V^{n s}$ & $\Lambda G Y Y^{* * *}$ & $r_{\circ} / \uparrow Q^{* * *}$ & r & بافت خاك × مقدار بقايا \\
\hline $1 \circ \wedge 0^{\mathrm{ns}}$ & $\mathrm{V} / 10^{* * * *}$ & $0 / 00019 \mathrm{~ns}$ & $\circ / \circ \circ \Delta Y^{n s}$ & $099 V Y^{* * *}$ & $\wedge / 11^{* * *}$ & r & بافت خاى × نوع بقايا \\
\hline Mrg & ns $\circ / \circ 0$ & $\circ / 0 \circ \circ Y V^{n s}$ & \%००M ns & $\Delta \circ \circ \Delta r^{* * *}$ & ns $/ / r$ & 1 & مقدار بقايا × نوع بقايا \\
\hline$\Delta Q^{\mathrm{ns}}$ & $r / 9 Y^{* *}$ & $0 / 0 \circ 0 / \mathbb{F}^{\mathrm{ns}}$ & $0 / 0049$ ns & qrvq *** & $9 / \Gamma)^{* * *}$ & r & بافت خاك × مقدار بقايا × نوع بقايا \\
\hline$I V \circ Y^{\mathrm{ns}}$ & $r / \varphi_{0} * * *$ & $\circ / \circ \circ \circ \Delta \Delta^{\mathrm{ns}}$ & $\circ / 0001$ ns & 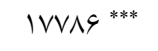 & $1 \Lambda / T Q^{* * *}$ & $r$ & مقايسه شاهدها \\
\hline Irquns & $\Delta / \circ V^{* *}$ & ०००५ด9** & $\circ / \circ \circ \varphi_{\text {Q ns }}$ & IrAVY。*** & $119 / 9 r^{* * *}$ & 1 & مقايسه شاهد با ساير تيمارها \\
\hline$\uparrow \wedge \Delta$ & $\circ / 4 V$ & O/O००YV & \% \% & 90 &.$/ 0 \wedge$ & ro & خطا \\
\hline
\end{tabular}

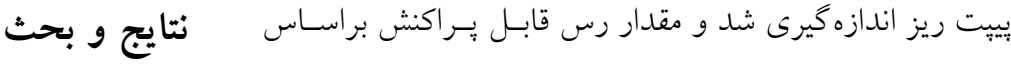

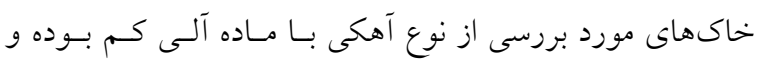
رس كل خاك بيان كرديد.

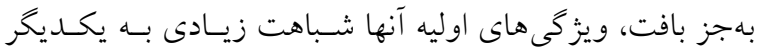

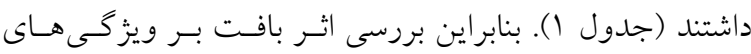

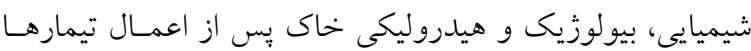

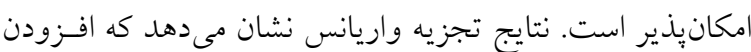
بقاياى كياهى به خاك از هر نوع و در هـــ مقــار سـبب ايجــاد

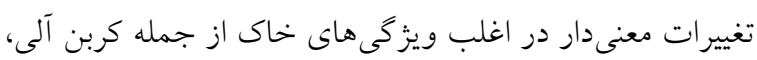

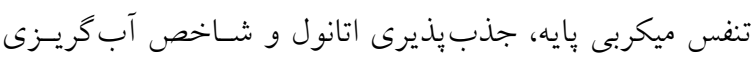

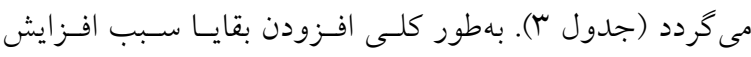

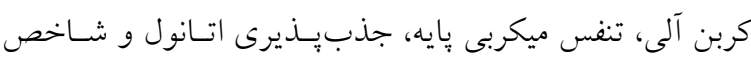

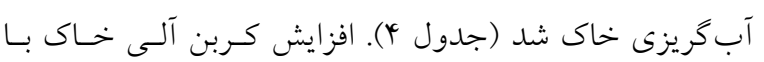

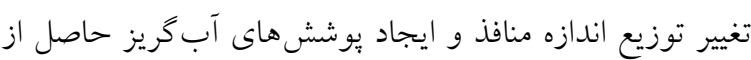

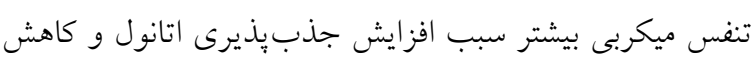

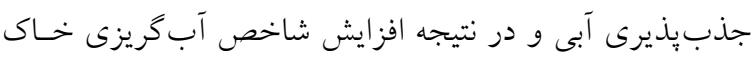
شد.

بافت خـاك اثـر معنـى دارى بــر مقــدار كـربن آلىى، تـنفس

\section{تجزيه و تحليل آمارى دادهها} با توجه به اين كه براى سطح صفر بقايا (شاهد)، نوع بقايا متغير

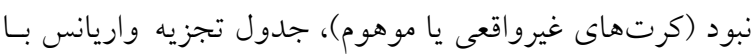

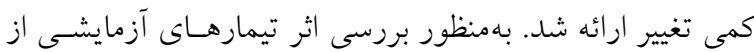

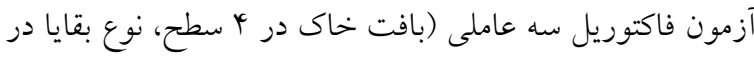

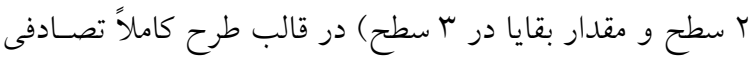
با ب تكرار استفاده شد. براى مقايسه شاهدها و همجنين مقايسـه

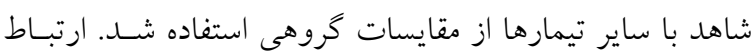

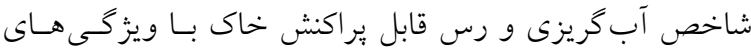

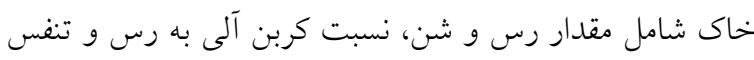

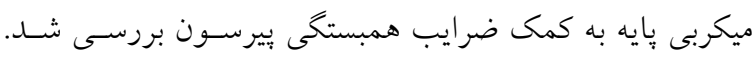

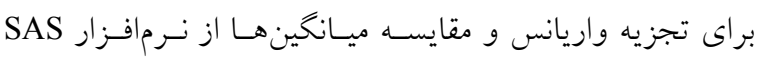

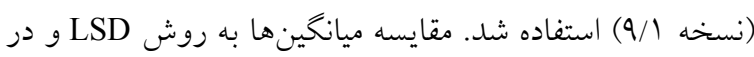

$$
\text { سطح احتمال ه درصد انجام كرفت. }
$$


جدول f. مقايسه ميانگين اثر مقدار بقايا بر كربن آلى (SOC)، تنفس ميكربى بايه (BSR)، جذبِّيرى آبى (Sw)، جذبِيذيرى اتانول

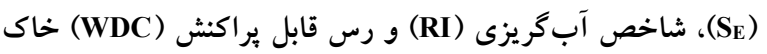

\begin{tabular}{|c|c|c|c|c|c|c|}
\hline $\begin{array}{c}\text { WDC } \\
\text { كيلو گرم رسر بر) }\end{array}$ & RI & 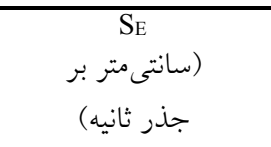 & 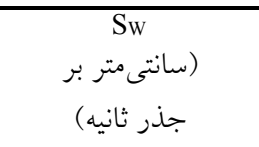 & 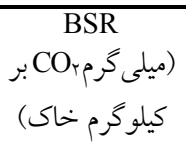 & $\begin{array}{c}\text { SOC } \\
\text { (خرم بر كيلوگرم) }\end{array}$ & (درصد وزنى مقار بقايا \\
\hline $9 \mathrm{~s} / \Lambda \pm(9 / 1)$ & $Q / \circ Y \pm\left(\circ / \Gamma_{\circ}\right)$ & 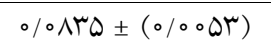 & 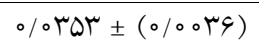 & $r \Lambda I \pm\left(r_{0}\right)$ & $N / T^{4} \pm(0 / 90)$ & 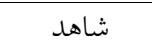 \\
\hline$\Delta Q / T \pm(V / 0)^{\mathrm{a}}$ & $g / 44 \pm(0 / V Q)^{a}$ & $0 / 1000 \pm(0 / 0 \circ \mu y)^{a}$ & $.0419 \pm(0 / 0040)^{a}$ & $r \omega \circ \pm(1)^{\mathrm{b}}$ & $10 / Y_{0} \pm(0 / 01)^{\mathrm{b}}$ & 1 \\
\hline$\hat{\varphi} \boldsymbol{y} / \mathrm{q} \pm(Q / \mathrm{l})^{\mathrm{b}}$ & $\Delta / \circ \Delta \pm\left(\circ / \varphi_{0}\right)^{b}$ & 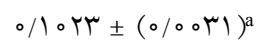 & $0 / 0991 \pm(0 / 01 \wedge 4)^{a}$ & $\operatorname{ror} \pm(T \varphi)^{\mathrm{a}}$ & $\mid r / \mu \psi t(0 / \mu y)^{a}$ & $r$ \\
\hline
\end{tabular}

مقايسه ميانخين براساس مقدار بقايا صورت كرفته و رديف شاهد تنها جهت مقايسه ارائه شده است. در هر سـتون اعـداد داراى حسروف مختلـف تفاوت معنى دار دارند (LSD, P<०/०ه). اعداد داخل :يرانتز مقادير خطاى معيار مىباشند.

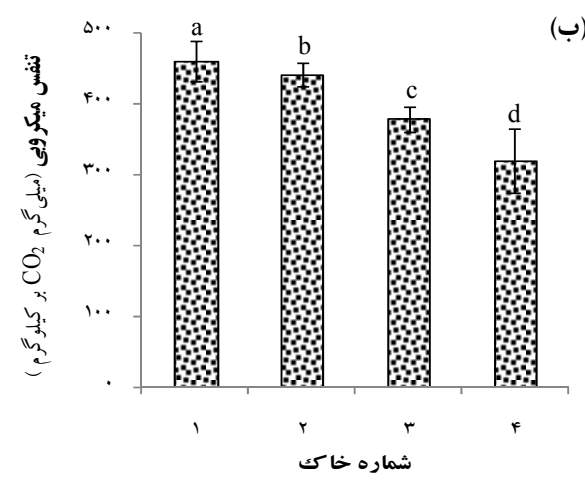

$(ب)$
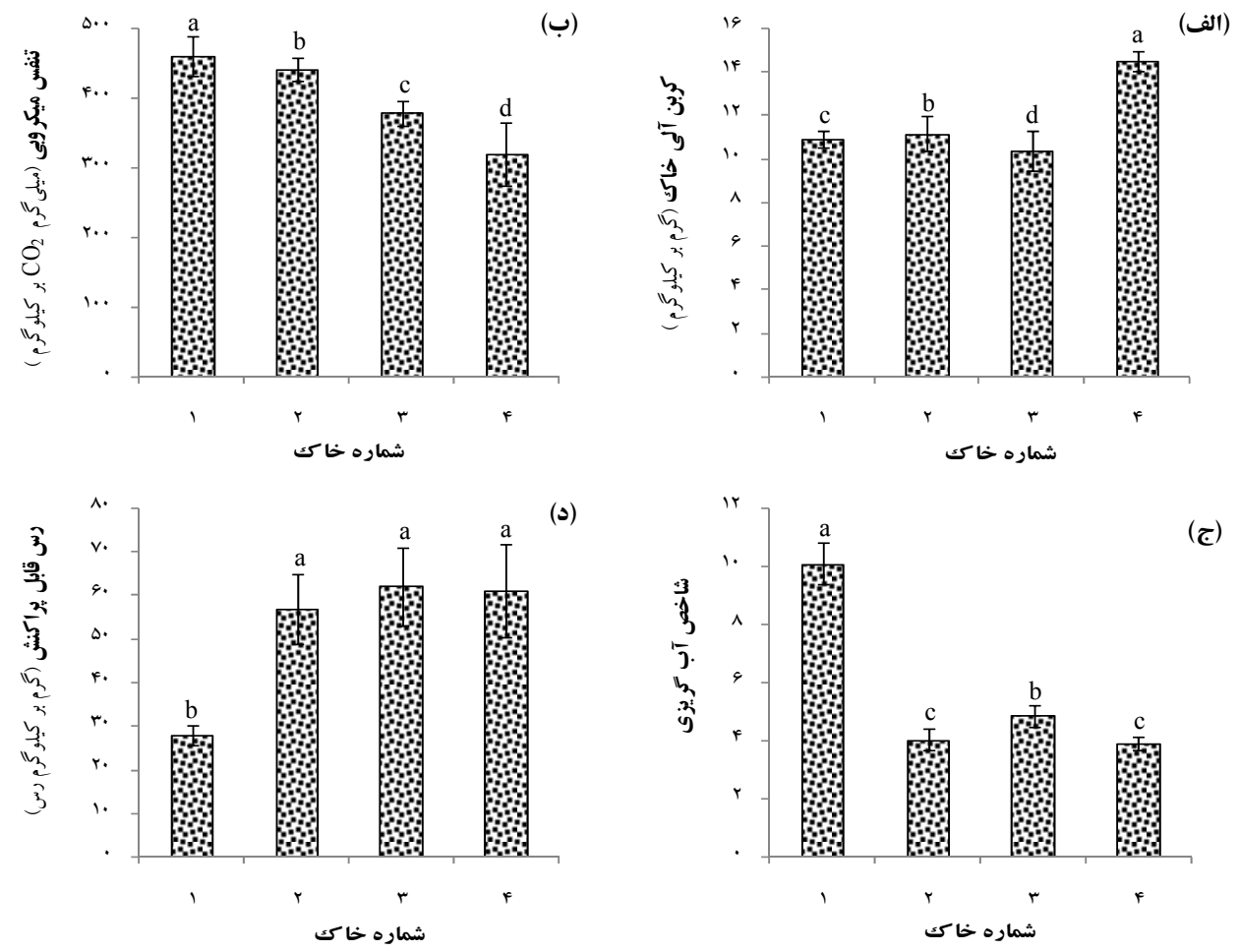

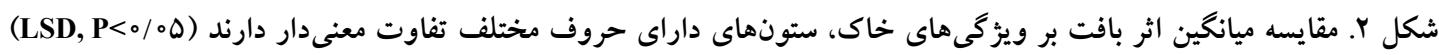

علاوه همبستخى منفى و معنسى دارى بـين مفـدار رس خـاك و تنفس ميكربى بايه مشاهده شد (r مىرسد كه افزايش مقدار رس با محدوديت تهويه سبب كاهش فعاليتهاى ميكربى و در نتيجه انباشت مواد آلى در خاك شـده است. جيندالوانگ و همكاران نيز گزارش نمودند كه با درنظـر كرفتن ورودى يكسان مواد آلى، خـاى هـاى ريزبافـت بـهـ دليـل
ميكربى، رس قابل براكنش و شاخص آبكُ شيزى خـاك داشـت

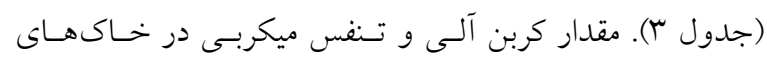
ريزبافت بهترتيب بيشتر و كمتر از خاكهاى درشتبافت اسـت

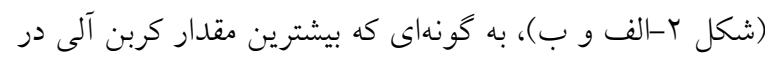

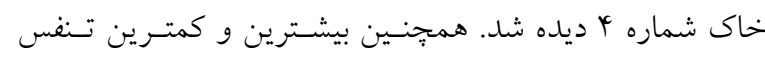
ميكربى خاى بهترتيب در خاكهاى شماره ا و با ديلده شد. بـه 
(†). همبستخى منفى و معنى دار بين رس قابل ير اكنش و نسـبت

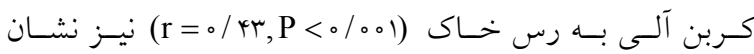

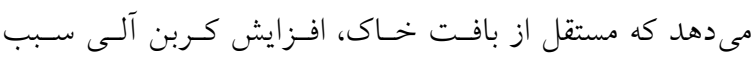
كاهش رس قابل براكنش (افزايش بايدارى ساختمان) خاك شدر.

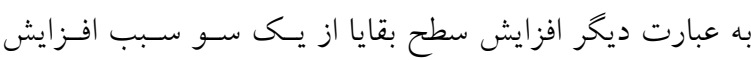

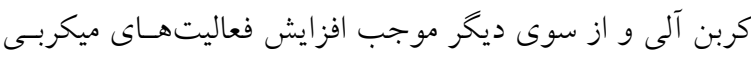

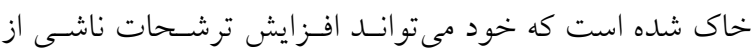

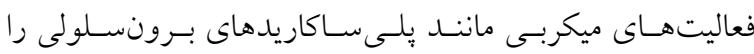

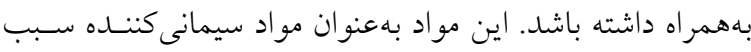

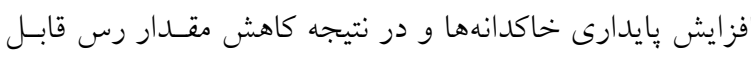

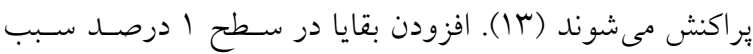

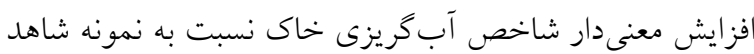

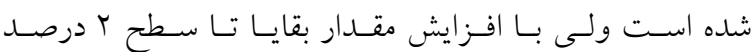

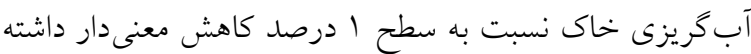

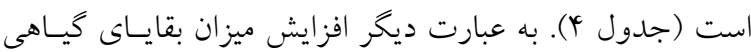

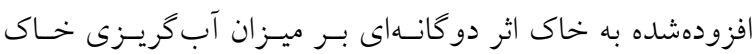

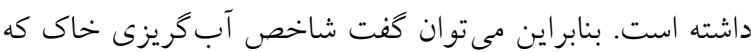

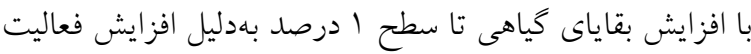

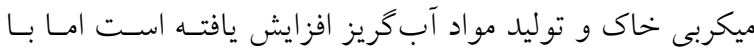

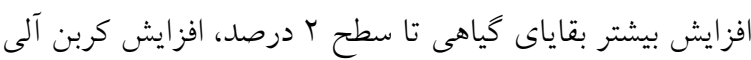
خاك سبب افزايش تخلخل كل شده و با افزايش در مقايسه

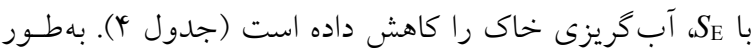
مشابه كوسنتينو و همكاران نيز دريافتند كه افزودن بقايـاى ذرت

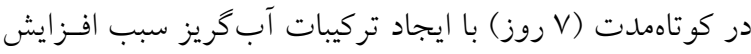
آب كُيزى خاك و در درازمدت (ها آروز) با افزايش تخلخـل

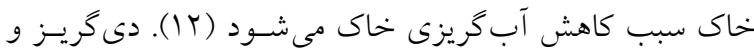
همكاران نيز گزارش نمودند كه افزودن بقاياى گنــدم بـه خــاك سبب افزايش تخلخل يا تغيير توزيع اندازه منافذ خـاك بـهـ ويـرَه در مجاورت بقايا مى گردد (r) (1).

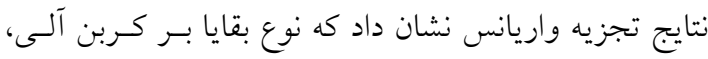

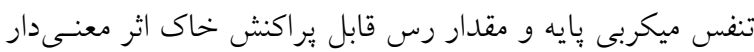
داشت (جدول ؟). شكل (r) نشان مى دهد كه حضور انـدوفيت
حفاظت فيزيكى از مواد آلى داراى كربن آلى بيشترى نسبت بـهـ

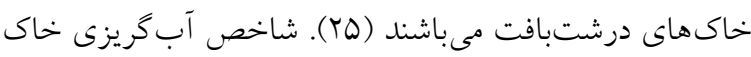

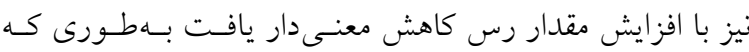

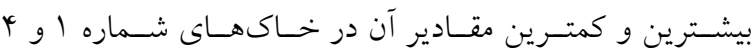

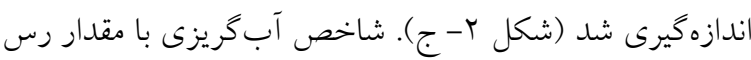

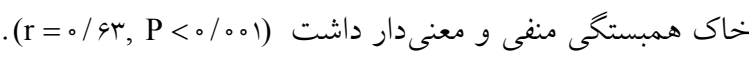

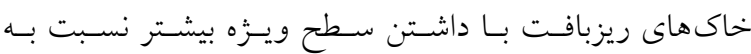

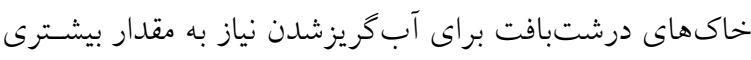

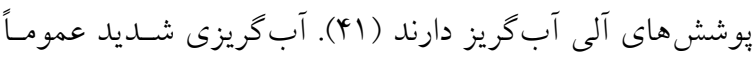

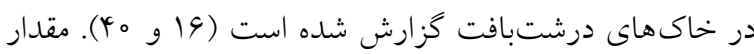

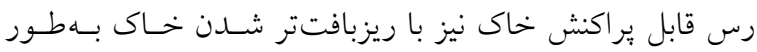

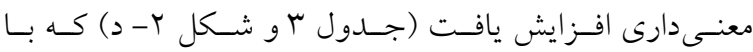

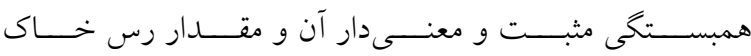

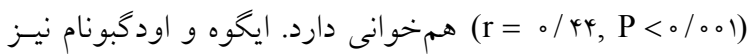

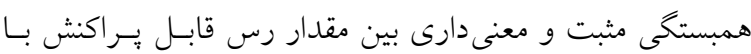
مقدار رس در خاكهاى جنوب نيجريه مشاهده نمودند (Tr).

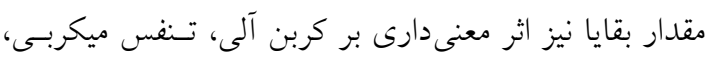

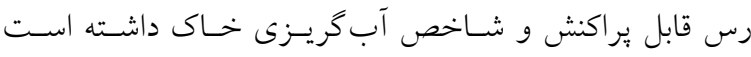

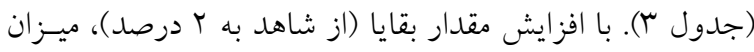

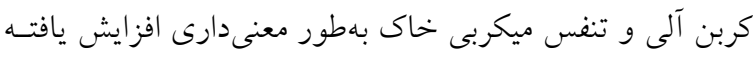

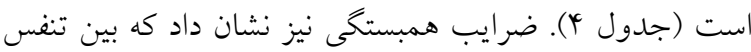

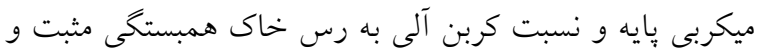

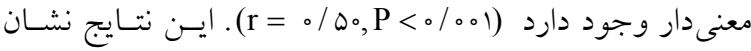
مىدهد كه صرفنظر از بافت، افزايش ماده آلى سـبب افـزايش تنفس ميكربى خاك مى شود. بركن و همكاران نيز دريافتند كه با تاب

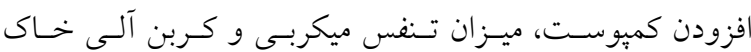
افزايش مى يابد (9). جعفرى و همكاران نيز دريافتند كه كاربرد

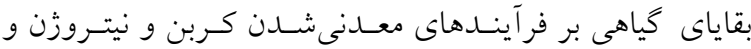

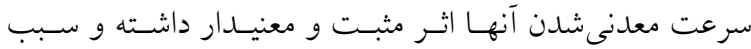
افزايش معدنىشدن كربن تا ب برابر كرديد (Y). افـزايش مقــدار

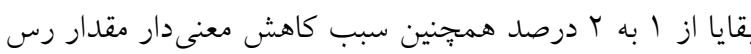

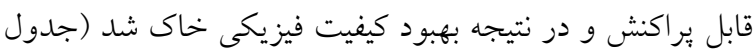




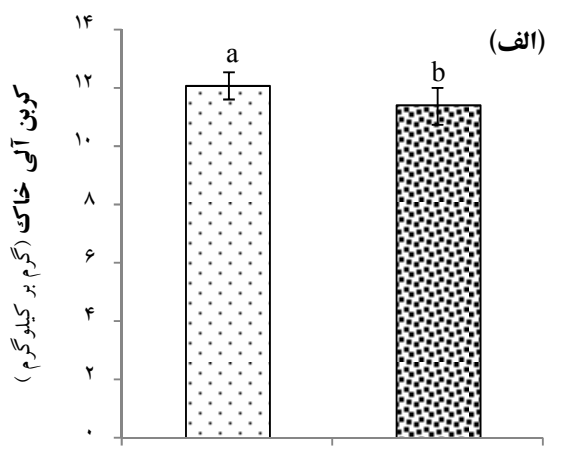

E+

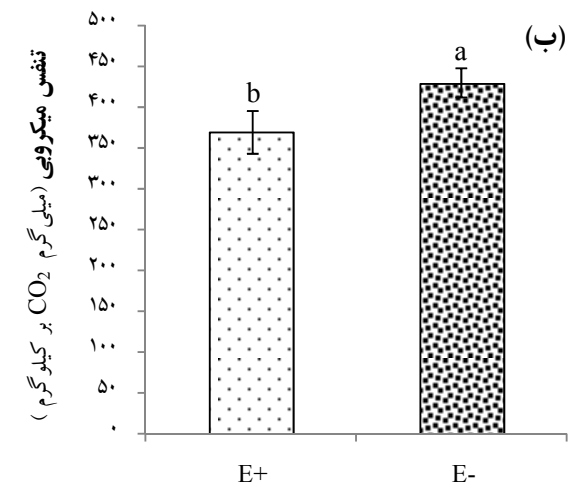

نوع بقايا

نوع بقايا

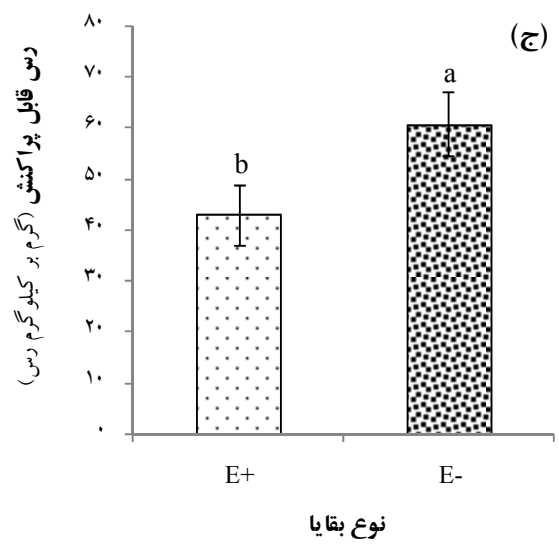

شكل r. مقايسه ميانگين اثر نوع بقايا (حاوى اندوفيت (E+) و عارى از اندوفيت (E-)) بر ويزگگهاى خاك

ستونهاى داراى حروف مختلف تفاوت معنىدار دارند (هـ/。

در كياه سبب كاهش تجزيه ميكربسى بقايساى گيـاهى و انباشـت كربن آلى در خاك شده است (1/). فرانزلوئبرز و همكاران نيـز لئز

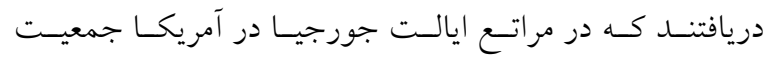
كستردهاى از گياهان فسكيوى بلند حاوى اندوفيت وجـود دارد

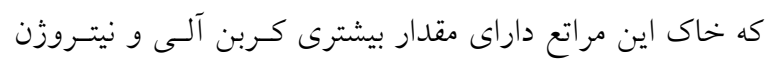
كل بوده و فعاليت ميكربى آن كمتر است (IV). نتايج اماسينى و همكاران در آرزانتين نيز نشـان داد كـهـ سـرعت تجزيـهـ بقايـاى شاخسـاره راى خــراس ايتاليـيى (Lolium multiflorum Lam.) حاوى اندوفيت بهدليل حضور آلكالوئيدها و آثار سمى آنهـا بـر جمعيت هاى ميكربى تجزيه كننده خـاى در مقايسـه بـا كياهـان عارى از اندوفيت آهستهتر اسـت (Yr). بـه نظـر مسىرســ كـه افزايش بيشتر كربن آلى خاى در نمونههاى داراى بقاياى حاوى

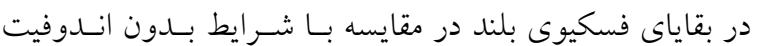
سبب افزايش كربن آلى، كاهش تــفس ميكربسى و كـاهش رس قابل براكنش خاك شده است. همجنــين، حضـور انـدوفيت در بقاياى گياهى در مقايسه بـا شـرايط عـارى از انـدوفيت سـبب

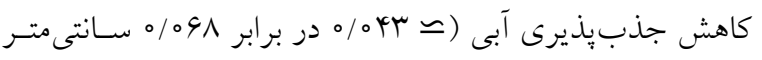

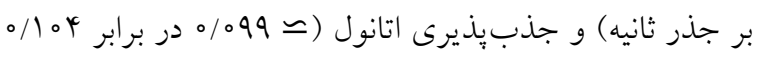
سانتى متر بر جذر ثانيه) و افـزايش شـاخص آبكريـزى خـاك

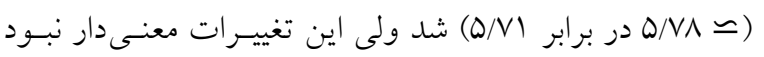

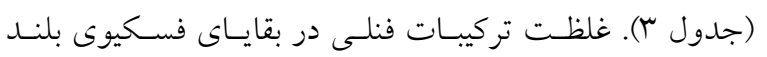
حاوى اندوفيت بيشتر از بقاياى عارى از اندوفيت است (جدول r). بنابر اين مىتوان كفت حضور قارجهـاى انـدوفيت و توليـد متابوليتهاى ثانويه مانند آلكالوئيدهاى مختلف و تركيبات فنلى 
و كمترين ميزان آبكريزى در تركيب خاك سا و دو درصد بقايا

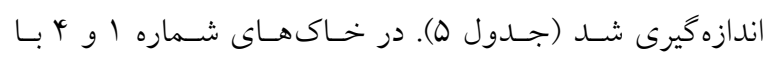

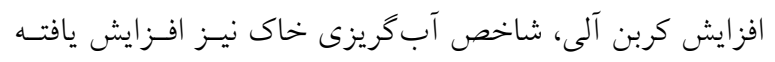

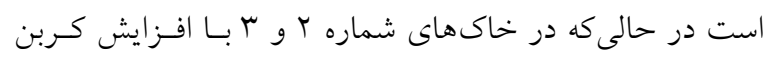

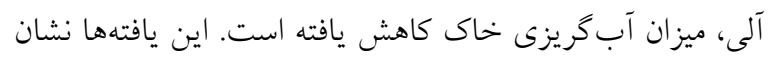

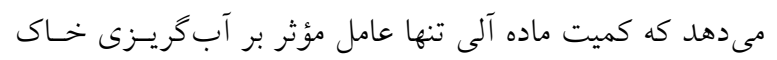

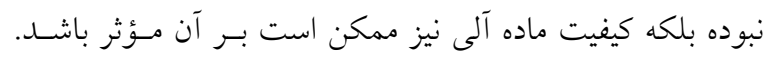

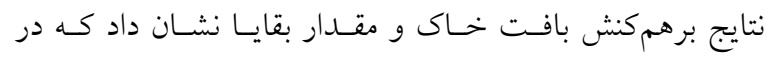

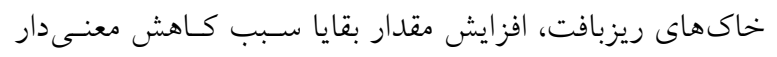

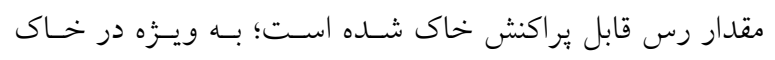

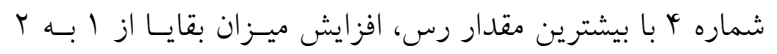

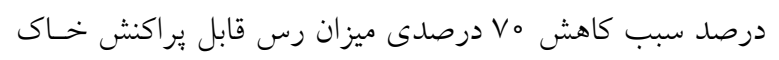

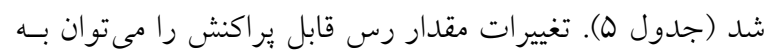

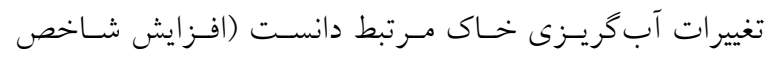

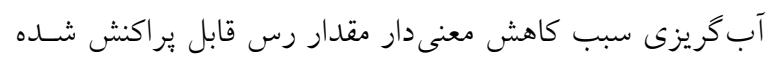

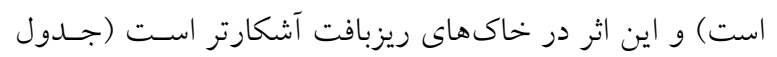

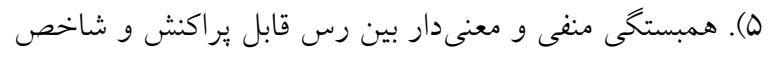

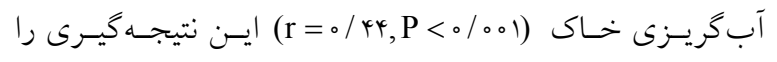

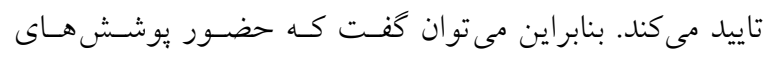

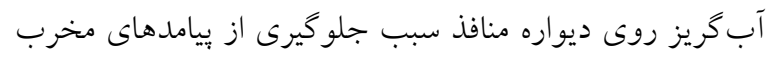

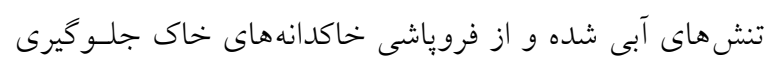

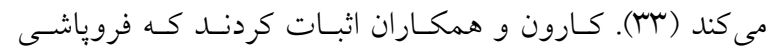

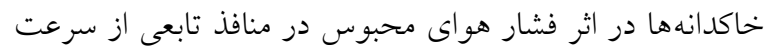

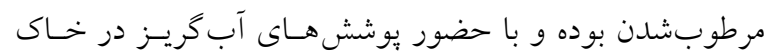

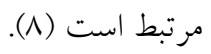

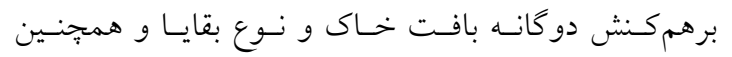

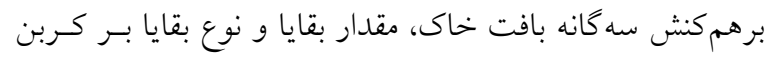

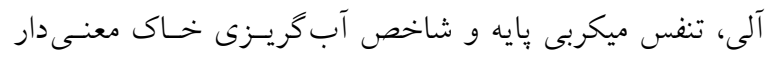

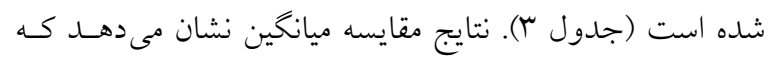

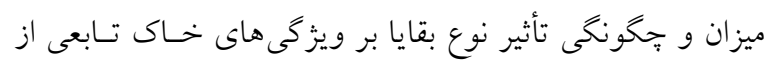
بافت خاك بوده و در خاكهاى با بافت متفـاوت اثـر يكسـانى نـاني

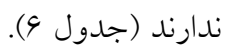

اندوفيت سبب پِايدارى بيشتر خاكدانسهـــا و كـاهش رس قابـل

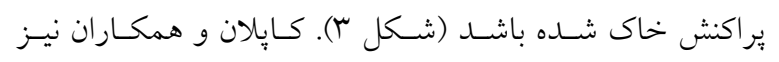

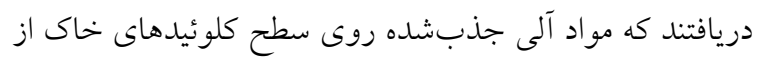

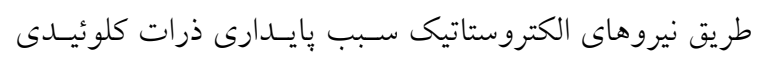
يراكنش يافته در محلول خاك مىشوند (Y) (Y).

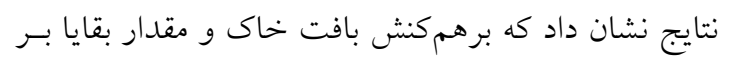

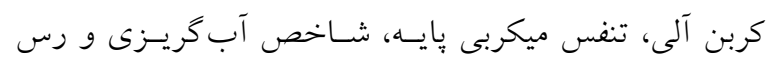

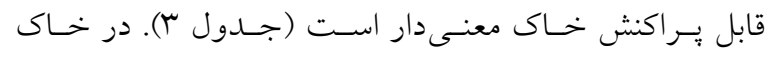
درشتبافت شماره ا (جدول ())، افزايش مقدار بقايا از إنسه

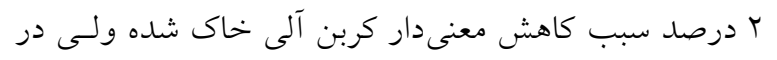
خاكهاى متوسط تا ريزبافت با افزايش مقدار بقاياى افزودهـ-

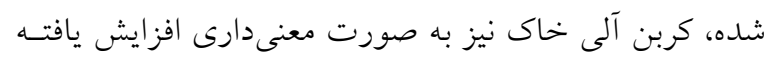

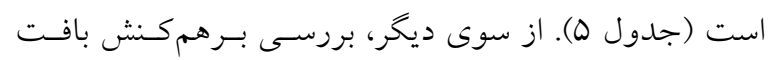

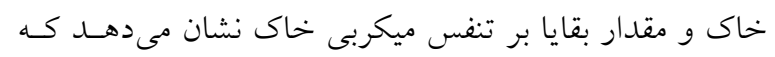

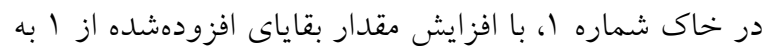

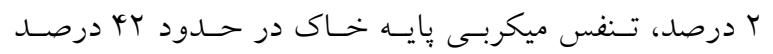

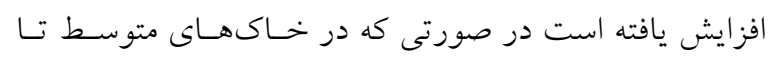

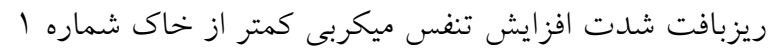

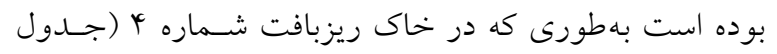

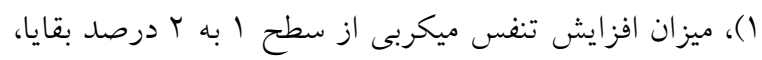

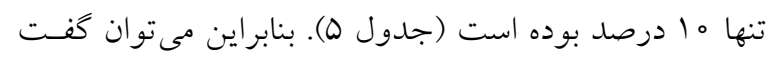

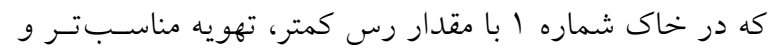

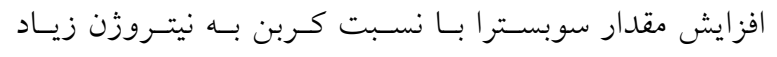

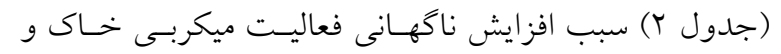

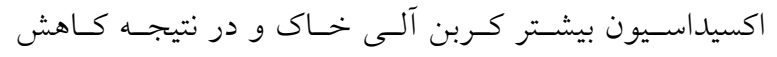

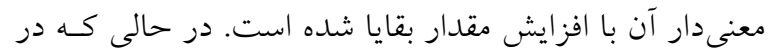

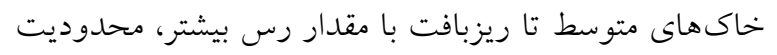

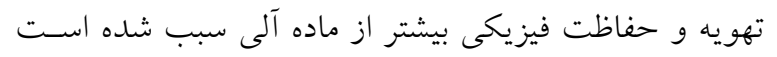

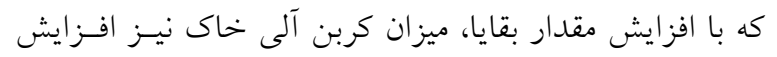

بررسى برهم كنش بافت خاك و مقــدار بقايـا نشـان داد كـهـ بيشترين ميزان آبكريزى در تركيب خاك آو و يكى درصد بقايـا 
جدول ه. مقايسه ميانكين برهم كنش بافت خاك و مقدار بقايا بر كربن آلى، تنفس ميكربى بايه، شاخص آبكريزى و رس قابل يراكنش خاك

\begin{tabular}{|c|c|c|c|c|c|}
\hline (كرم بر كيلوكرم رس رسب ) ركنش & شاخص آبكريزى & 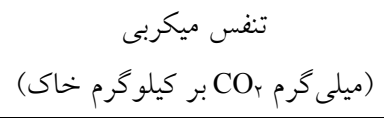 & (كرم بر كيلوكرم) & (درصد وزنى مقار بقايا & شماره خاك \\
\hline 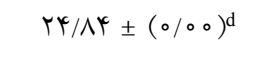 & $1 Y / 09 \pm\left(\circ / V{ }^{4}\right)^{a}$ & $r \Lambda r \pm(r I)^{e}$ & $11 / 11 \pm(0 / 11)^{d}$ & 1 & \multirow{2}{*}{1} \\
\hline$\Gamma / / 0 \varphi \pm(\Psi / Y Y)^{\mathrm{cd}}$ & $N / T T_{ \pm}(0 / T \varphi)^{b}$ & $\operatorname{Drr} \pm(r)^{\mathrm{a}}$ & $1 \circ / V^{4} \pm(\circ / V \varphi)^{e}$ & r & \\
\hline$\Delta \Gamma / \Gamma^{\prime} \pm\left(11 / \mathcal{G}^{\mu}\right)^{\mathrm{bc}}$ & $\gamma / 94 \pm(0 / 94)^{d}$ & $r 90 \pm(1 r)^{d}$ & $N / 9 \Lambda \pm\left(0 / \varphi_{0}\right)^{\mathrm{f}}$ & 1 & \multirow{2}{*}{ r } \\
\hline $90 / 91 \pm(11 / 94)^{b}$ & $r / 4 q \pm(0 / r \Delta)^{e}$ & $r q \circ \pm(I V)^{b}$ & $|r / V| \pm(0 / \mu)^{b}$ & r & \\
\hline$q 4 / V \circ \pm(\mid q / / Y)^{b}$ & $\Delta / V Q \pm(0 / F Q)^{c}$ & $\mu_{T} \circ \pm(1 \circ)^{g}$ & $V / \wedge \circ \pm(0 / 99)^{g}$ & 1 & \multirow{2}{*}{ r } \\
\hline$\Delta Q / \Delta r \pm(Q / T r)^{b}$ & $\varphi / \circ \circ \pm\left(\circ / \Gamma^{\mu} \varphi\right)^{\mathrm{de}}$ & $\forall \wedge \mu_{ \pm} \pm(V)^{c}$ & $\mid r / \circ r_{ \pm}(0 / \mid Q)^{c}$ & r & \\
\hline$q \Psi / 9 \Lambda \pm(\mathcal{F} / r V)^{\mathrm{a}}$ & $\left.r / r_{0} \pm(0 / r)\right)^{e}$ & $r \circ \Delta \pm(T q)^{\mathrm{h}}$ & $\mid r / r_{0} \pm(0 / / Y)^{c}$ & 1 & \multirow{2}{*}{$r$} \\
\hline$Y \Lambda / Y \circ \pm(\varphi / \Lambda \varphi)^{d}$ & $\varphi / \Delta Q \pm(0 / 10)^{d}$ & $M V_{ \pm}(\Lambda \Lambda)^{\mathrm{f}}$ & $10 / \wedge q \pm(\circ / \Gamma \Lambda)^{a}$ & r & \\
\hline TYMT & O/AV & 9 & $0 / \pi 1$ & \multicolumn{2}{|c|}{$\operatorname{LSD}_{\circ / \diamond \Delta}$} \\
\hline
\end{tabular}

در هر ستون اعداد داراى حروف مختلف تفاوت معنى دار دارند (LSD, P<0/0D). اعداد داخل برانتز مقادير خطاى معيار مىباشند

جدول 9. مقايسه ميانگين برهم كنش بافت خاك و نوع بقايا بر كربن آلى، تنفس ميكربى پايه و شاخص آبكريزى خاك

\begin{tabular}{|c|c|c|c|c|}
\hline شاخص آبكريزى & 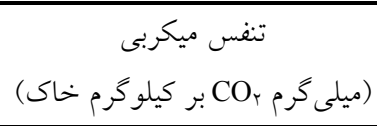 & 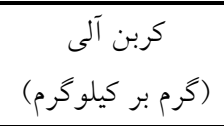 & نوع بقايا & شماره خاك \\
\hline $9 / 09 \pm(0 / 94)^{b}$ & $Y 90 \pm\left(Y_{\circ}\right)^{\mathrm{a}}$ & $11 / \Lambda F \pm(0 / T V)^{c}$ & E+ & \multirow{2}{*}{1} \\
\hline $11 / 1 \mu_{ \pm}(1 / 19)^{\mathrm{a}}$ & YYA $\pm(D I)^{\mathrm{c}}$ & $10 / 01 \pm\left(0 / \mathbb{k}^{\mathrm{c}}\right)^{\mathrm{f}}$ & $\mathrm{E}^{-}$ & \\
\hline$Y / Q \Lambda \pm(\circ / N Y)^{d}$ & $\operatorname{crv} \pm(\Lambda)^{\mathrm{c}}$ & $\| 1 / \circ \Lambda \pm(1 / \propto \vee)^{e}$ & $\mathrm{E}+$ & \multirow{2}{*}{ r } \\
\hline$r / \Delta Q \pm(0 / T Q)^{e}$ & $\mu \psi \wedge \pm(\Gamma Q)^{b}$ & $\| / / \mid \pm\left(0 / \Lambda_{0}\right)^{\text {de }}$ & $\mathrm{E}^{-}$ & \\
\hline$\Delta / \Delta V \pm(0 / \Psi V)^{c}$ & $\operatorname{rg} T \pm(T \Lambda)^{e}$ & $11 / 09 \pm(0 / V Y)^{\mathrm{cd}}$ & $\mathrm{E}+$ & \multirow{2}{*}{ r } \\
\hline $4 / 19 \pm(0 / 4 \Lambda)^{\mathrm{de}}$ & $r q \nabla \pm(r q)^{d}$ & $q / T^{Y} \pm\left(1 / q^{\varphi}\right)^{g}$ & E- & \\
\hline$\Gamma / \Lambda \vee \pm(\circ / \Gamma \Lambda)^{\mathrm{de}}$ & $190 \pm(T r)^{\mathrm{f}}$ & $1 \% / 99 \pm(0 / 4 V)^{b}$ & $\mathrm{E}+$ & \multirow{2}{*}{$\varphi$} \\
\hline$r / 9 \Lambda \pm(0 / r q)^{\mathrm{de}}$ & $\operatorname{rar} \pm\left(r^{\mathrm{V}}\right)^{\mathrm{b}}$ & $10 / \circ q \pm\left(\circ / V^{\top}\right)^{a}$ & $\mathrm{E}^{-}$ & \\
\hline$\circ / \mathrm{AV}$ & 9 & $0 / 4$ & \multicolumn{2}{|c|}{$\mathrm{LSD}_{\circ / \diamond}$} \\
\hline
\end{tabular}

در هر ستون اعداد داراى حروف مختلف تفاوت معنىدار دارند (LSD, P<o/0Q). اعداد داخل يرانتز مقادير خطاى معيار مىباشند.

با بهور كلى در خاكهاى ريزبافت، كربن آلى و رس قابـل

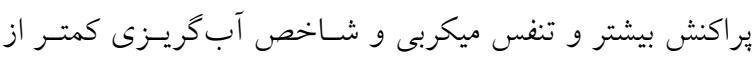

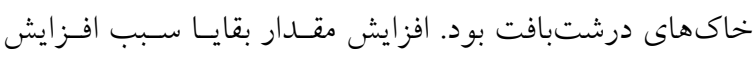

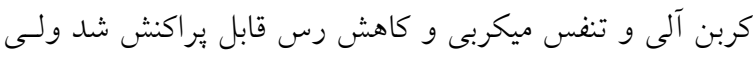

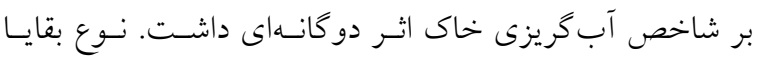

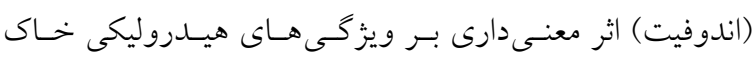

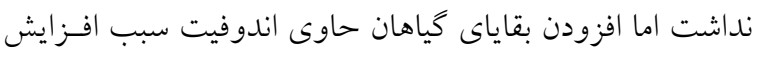

\section{نتيجه گيرى و بيشنهاد} 1) نتايج اين يزووهش نشان داد كه بقاياى كياه فسكيوى بلند بــهـ

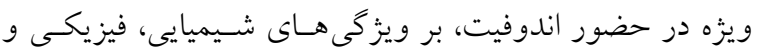

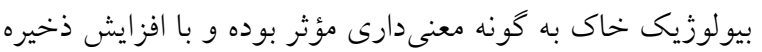

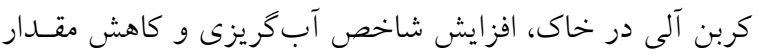

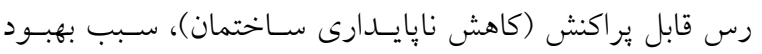
كيفيت فيزيكى و ساختمان خاك كرديدهاند. 


$$
\begin{aligned}
& \text { كربن آلى و كاهش معنى دار رس قابل بر اكنش خاك شد. احياى مراتع داشته و كاربرد آن بهدستكاههاى اجرايسى حفاظـت }
\end{aligned}
$$

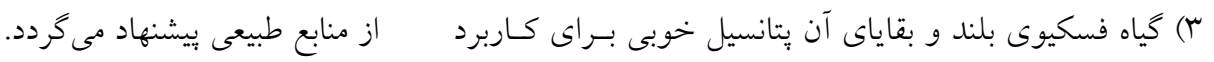

$$
\begin{aligned}
& \text { در طرحهاى حفاظت خاك در زمين هاى مرتعى و كشـاورزى و }
\end{aligned}
$$

$$
\begin{aligned}
& \text { منابع مورد استفاده }
\end{aligned}
$$

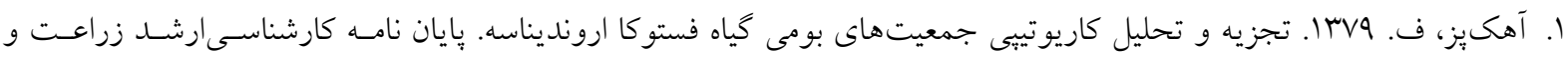

$$
\begin{aligned}
& \text { اصلاح نبات، دانشكده كشاورزى، دانشخاه صنعتى اصفهان. }
\end{aligned}
$$

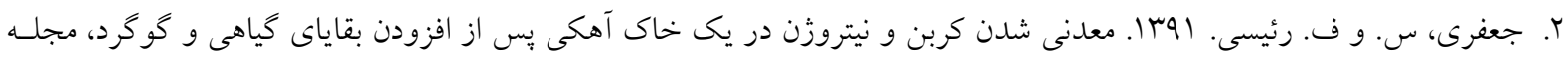

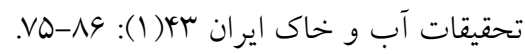

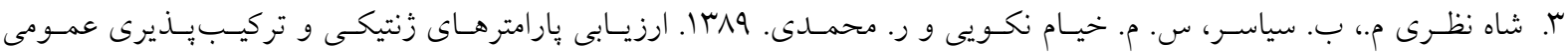

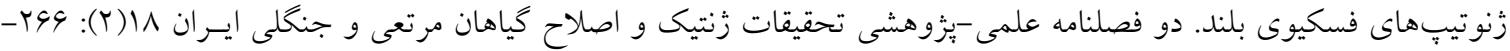

. Y Yq

4. Bachmann, J., R. Horton and R. R. Van Der Ploeg. 2001. Isothermal and nonisothermal evaporation from four sandy soils of different water repellency. Soil Sci. Soc. Am. J. 65: 1599-1607.

5. Beta, T., S. Nam, J. E. Dexter and H. D. Sapirstein. 2005. Phenolic content and antioxidant activity of pearled wheat and roller-milled fractions. Cereal Chem. 82: 390-393.

6. Borken, W., A. Muhs and F. Beese. 2002. Changes in microbial and soil properties following compost treatment of degraded temperate forest soils. Soil Biol. Biochem. 34: 403-412.

7. Burt, R., T. G. Reinsch and W. P. Miller. 1993. A micro-pipette method for water dispersible clay. Commun. Soil Sci. Plant Anal. 24: 2531-2544.

8. Caron, J., C. R. Espindola and D. A. Angers. 1996. Soil structural stability during rapid wetting: Influence of land use on some aggregate properties. Soil Sci. Soc. Am. J. 60: 901-908.

9. Castellini, M., M. Niedda, M. Pirastru and D. Ventrella. 2014. Temporal changes of soil physical quality under two residue management systems. Soil Use Manage. 30: 423-434.

10. Chau, H. W., Y. K. Goh, V. Vujanovic and B. C. Si. 2012. Wetting properties of fungi mycelium alter soil infiltration and soil water repellency in a $\gamma$-sterilized wettable and repellent soil. Fungal Biol. 116: 1212-1218.

11. Chen, C. R., L. M. Condron, M. R. Davis and R. R. Sherlock. 2000. Effects of aforestation on phosphorus and biological properties in a New Zealand grassland soil. Plant Soil. 220: 151-163.

12. Cosentino, D., P. D. Hallett, J. C. Michel and C. Chenu. 2010. Do different methods for measuring the hydrophobicity of soil aggregates give the same trends in soil amended with residue? Geoderma 159: 221-227.

13. De Gryze, S., L. Jassogne, J. Six, H. Bossuyt, M. Wevers and R. Merckx. 2006. Pore structure changes during decomposition of fresh residue: X-ray tomography analyses. Geoderma 134: 82-96.

14.Dekker, L. W., S. H. Doerr, K. Oostindie, A. K. Ziogas, J. Coen. 2001. Water repellency and critical soil water content in a dune sand. Soil Sci. Soc. Am. J. 65: 1667-1674.

15.Doerr, S. H. and A. D. Thomas. 2000. The role of soil moisture in controlling water repellency: new evidence from forest soils in Portugal. J. Hydrol. 231: 134-147.

16. Doerr, S. H. R. A. Shakesby, L. W. Dekker and C. J. Ritsema. 2006. Occurrence prediction and hydrological effects of water repellency amongst major soil and land-use types in a humid temperate climate. Eur. J. Soil Sci. 57: 741754.

17.Franzluebbers, A. J. N. Nazih, J. A. Stuedemann, J. J. Fuhrmann, H. H. Schomberg and P. G. Hartel. 1999. Soil carbon and nitrogen pools under low-and high-endophyte-infected tall fescue. Soil Sci. Soc. Am. J. 63: 1687-1694.

18. Franzluebbers, A. J. and N. S. Hill. 2005. Soil carbon, nitrogen, and ergot alkaloids with short-and long-term exposure to endophyte-infected and endophyte-free tall fescue. Soil Sci. Soc. Am. J. 69: 404-412.

19. Håkansson, I. 1990. A method for characterizing the state of compactness of the plough layer. Soil Tillage Res. 16: 105-120.

20. Hallett, P. D. and I. M. Young. 1999. Changes to water repellence of soil aggregates caused by substrate-induced microbial activity. Eur. J. Soil Sci. 50: 35-40. 
21.Hallett, P. D., D. C. Gordon and A. G. Bengough. 2003. Plant influence on rhizosphere hydraulic properties: direct measurements using a miniaturized infiltrometer. New Phytol. 157: 597-603.

22. Hallett, P. D. 2007. An introduction to soil water repellency. In: Proceedings of the $8^{\text {th }}$ International Symposium on Adjuvants for Agrochemicals Vol. 6, p. 9.

23. Igwe, C. A. and O. N. Udegbunam. 2008. Soil properties influencing water-dispersible clay and silt in an Ultisol in southern Nigeria. Int. Agrophys 22: 319-325.

24.Iqbal, J., J. A. Siegrist, J. A. Nelson and R. L. McCulley. 2012. Fungal endophyte infection increases carbon sequestration potential of southeastern USA tall fescue stands. Soil Biol. Biochem. 44: 81-92.

25.Jindaluang, W., I. Kheoruenromne, A. Suddhiprakarn, B. P. Singh and B. Singh. 2013. Influence of soil texture and mineralogy on organic matter content and composition in physically separated fractions soils of Thailand. Geoderma 195: 207-219.

26.Kaplan, D. I., P. M. Bertsch and D. C. Adriano. 1997. Mineralogical and physicochemical differences between mobile and non-mobile colloidal phases in reconstructed pedons. Soil Sci. Soc. Am. J. 61: 641-649.

27.Kong, L., F. Si J. Wang, B. Feng and S. Li. 2008. Water-soluble phenolic compounds in the coat control germination and peroxidase reactivation in Triticum aestivum seeds. Plant Growth Regul. 56: 275-283.

28.Kostka, S. J. 2000. Amelioration of water repellency in highly managed soils and the enhancement of turfgrass performance through the systematic application of surfactants. J. Hydrol. 231: 359-368.

29.Lemons, A., K. Clay and J. A. Rudgers. 2005. Connecting plant-microbial interactions above and belowground: a fungal endophyte affects decomposition. Oecologia 145: 595-604.

30.Lipiec, J., A. Wojciga and R. Horn. 2009. Hydraulic properties of soil aggregates as influenced by compaction. Soil Tillage Res. 103: 170-177.

31. Malinowski, D. P. and D. P. Belesky. 2000. Adaptations of endophyte-infected cool-season grasses to environmental stresses: mechanisms of drought and mineral stress tolerance. Crop Sci. 40: 923-940.

32. Omacini, M. J., E. M. Chaneton, C. Ghersa and P. Otero. 2004. Do foliar endophytes affect grass litter decomposition? A microcosm approach using Lolium multiflorum. Oikos 104: 581-590.

33.Piccolo, A. and J. S. Mbagwu. 1999. Role of hydrophobic components of soil organic matter in soil aggregate stability. Soil Sci. Soc. Am. J. 63: 1801-1810.

34. Richards, L. A. 1954. Diagnosis and Improvement of Saline and Alkali soils. United States Department of Agriculture, Handbook no. 60. 102 pp. Washington, DC.

35. Sabzalian, M. R. and A. Mirlohi. 2010. Neotyphodium endophytes trigger salt resistance in tall and meadow fescues. J. Plant Nutr. Soil Sci. 173: 952-957.

36. Saha, D. C., M. A. Jackson and J. M. Johnson-Cicalese. 1988. A rapid staining method for detection of endophytic fungi in turf and forage grasses. Phytopathology 78: 237-239.

37. Strudley, M. W., T. R. Green and J. C. Ascough. 2008. Tillage effects on soil hydraulic properties in space and time: State of the science. Soil Tillage Res. 99: 4-48.

38.Tillman, R. W., D. R. Scotter, M. G. Wallis and B. E. Clothier. 1989. Water repellency and its measurement by using intrinsic sorptivity. Aust. J. Soil Res. 27: 637-644.

39. Vogelmann, E. S., J. M. Reichert, J. Prevedello and G. O. Awe. 2013. Hydro-physical processes and soil properties correlated with origin of soil hydrophobicity. Cienc. Rural. 43: 1582-1589.

40.Wahl, N. A. 2008. Variability of water repellency in sandy forest soils under broadleaves and conifers in northwestern Jutland/Denmark. Soil Water Res. 3: S155-S164.

41. Wallis, M. G. and D. J. Horne. 1992. Soil Water Repellency. PP: 91-146. In: Stewart, B.A. (Ed.), Advances in Soil Science. Springer. New York. 


\title{
Effects of Endophyte-infected (Epichloë coenophaila) Tall Fescue Residues on Water Repellency and Structural Stability of Texturally- Different Soils
}

\author{
F. Hosseini ${ }^{* 1}$, M. R. Mosaddeghi ${ }^{1}$, M. A. Hajabbasi ${ }^{1}$, M. R. Sabzalian ${ }^{2}$, \\ M. Soleimani ${ }^{3}$ and M. Sepehri ${ }^{4}$
}

(Received: Feb. 03-2015; Accepted: Sept. 06-2016)

\begin{abstract}
Soil water repellency can affect several soil properties such as aggregate stability. Soil texture and organic matter are two main internal factors responsible for the variability of soil water repellency. Major sources of organic matter in soil include plant residues, and exudates of plant roots and soil microorganisms. Tall fescue (Festuca arundinacea Schreb.) as an important cool-season perennial forage grass is usually infected by a fungal endophyte (Epichloë coenophiala) which often enhances resistance to biotic and abiotic stresses as well as altering the litter decomposition rate and soil properties. In this study, the effects of endophyte-infected $(\mathrm{E}+)$ and endophyte-free $\left(\mathrm{E}^{-}\right)$tall fescue residues (in three different levels of 0,1 and $2 \%$ ) on soil organic carbon, basal microbial respiration, water-dispersible clay and water repellency index (determined by intrinsic sorptivity method) were investigated in four texturally-different soils in the laboratory. E+ and E- tall fescue residues were completely mixed with moist soil samples and then were incubated at $25^{\circ} \mathrm{C}$. During two months of incubation period, the amended soil samples were subjected to 10 wetting and drying cycles and then, the above-mentioned soil properties were measured. The results indicated that soil organic carbon and water-dispersible clay were greater, while basal soil respiration and repellency index were lower in fine-textured soils. Water repellency index was increased by production of hydrophobic substances (for the rate of $1 \%$ ) and was reduced by induced greater soil porosity (for the rate of $2 \%$ ). Presence of endophyte in plant residues had no significant effect on water sorptivity, ethanol sorptivity and water repellency index; nevertheless, E+ residues increased soil organic carbon and decreased water-dispersible clay significantly. Overall, it is concluded that tall fescue residues, especially those with $\mathrm{E}+$, can improve soil physical quality due to improving soil organic carbon storage and water repellency index and decreasing water-dispersible clay (as an index for aggregate instability). These $\mathrm{E}+$ species and the residues have great potential to be used in sustainable soil conservational managements.
\end{abstract}

Keywords: Water repellency index, Endophyte, Water-dispersible clay, Tall fescue, Water sorptivity, Ethanol sorptivity.

1. Dept. of Soil Sci., College of Agric., Isfahan Univ. of Technol., Isfahan, Iran.

2. Dept. of Agronomy and Plant Breeding, College of Agric. Isfahan Univ. of Technol., Isfahan, Iran.

3. Dept. of Natural Resources, Isfahan Univ. of Technol., Isfahan, Iran.

4. Dept. of Soil Sci., College of Agric., Shiraz Univ., Shiraz, Iran.

*: Corresponding Author, Email: baharehhosseini64@gmail.com 